\title{
A COMBINED MULTI-ANALYTICAL APPROACH FOR THE STUDY OF ROMAN GLASS FROM SOUTH-WEST IBERIA: SYNCHROTRON $\mu$-XRF, EXTERNAL-PIXE/PIGE AND BSEM-EDS*
}

\author{
N. SCHIAVON, ${ }^{1}$ A. CANDEIAS,${ }^{2}$ T. FERREIRA, ${ }^{2}$ M. DA CONCEIÇAO LOPES, ${ }^{3}$ \\ A. CARNEIRO,${ }^{4}$ T. CALLIGARO ${ }^{5}$ and J. MIRAO ${ }^{1} \dagger$
${ }^{1}$ Hercules Laboratory for the Study and Conservation of Cultural Heritage and Evora Geophysics Centre, University of Evora, Largo Marqués de Marialva 8, 7000-809, Evora, Portugal Largo Marqués de Marialva 8, 7000-809, Evora, Portugal
${ }^{3}$ Centro de Estudos Arqueológicos das Universidades de Coimbra e Porto (CEAUCP)—University of Coimbra, Coimbra, Portugal
${ }^{4}$ Centre for Art History and Artistic Research (CHAIA) University of Evora, Evora, Portugal Paris, France \\ ${ }^{2}$ Hercules Laboratory for the Study and Conservation of Cultural Heritage and Evora Chemistry Centre, University of Evora, \\ ${ }^{5}$ AGLAE Accelerator Unit-Laboratoire du Centre de Recherche et de Restauration des Musées de France, Louvre Museum,
}

\begin{abstract}
An integrated, multi-analytical approach combining the high sensitivity of $S R-\mu X R F$, the light element capability of PIXE/PIGE under a helium flux and the spatial resolution of $B S E M+E D S$ was used to characterize chemical composition and corrosion of glass samples (first to fourth centuries $A D$ ) from an important, but scarcely investigated, Roman region of south-west Iberia (southern Portugal). The geochemical trends and associations of major, minor and trace elements were investigated to shed light on production techniques, the provenance of raw materials and decay mechanisms. The results, while confirming a production technique common to Roman glasses throughout the Empire-that is, a silica-soda-lime low-Mg, low-K composition, with glass additives as colouring and/or decolouring agents (Fe, $\mathrm{Cu}, \mathrm{Mn}, \mathrm{Sb}$ )—show at one site high $\mathrm{Zr}$-Ti contents, suggesting a more precise dating for these glasses to the second half of the fourth century. The Ti-Fe-Zr-Nb geochemical correlations in the pristine glass indicate the presence of minerals such as ilmenite, zircon, Ti-rich Fe oxides and columbite in the sands used as raw materials for the glass former: these minerals are typical of granitic-type source rocks. The unusually high $K$ content in the corrosion layers is consistent with burial conditions in $K$-rich soils derived from the alteration of 2:1 clays in K-bearing rock sequences.
\end{abstract}

KEYWORDS: ROMAN GLASS, SOUTH-WEST IBERIA, SR- $\mu$ XRF, PIXE/PIGE, BSEM + EDS

\section{INTRODUCTION}

In Roman times, the Iberian Peninsula - and, in particular, its south-westernmost part, the province called Lusitania (Fig. 1) -was regarded as a particularly important region of the Empire due to its wealth of natural assets, such as $\mathrm{Au}, \mathrm{Ag}, \mathrm{Pb}, \mathrm{Sn}$ and $\mathrm{Cu}$ ores, highly fertile soils and marine resources (Barriga and Fyfe 1998; Leistel et al. 1998). For the purpose of the present study, fragments of glass artefacts from two archaeological excavations situated near the towns of Fronteira (a Roman rural villa in the São Pedro locality: third to fourth centuries AD) and Beja

\footnotetext{
*Received 21 July 2011; accepted 10 January 2012

†Corresponding author: email jmirao@uevora.pt

(C) University of Oxford, 2012
} 


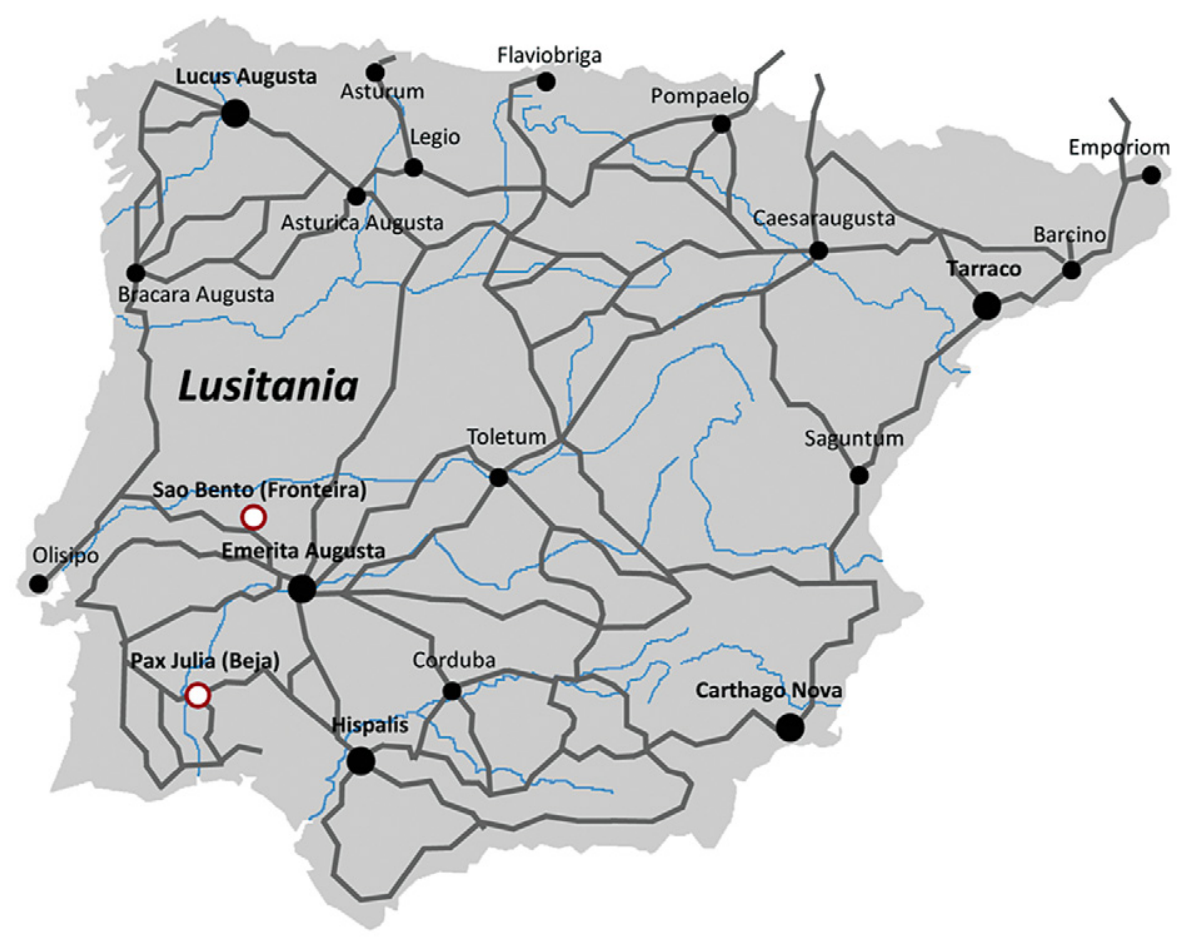

Figure 1 A map of the Iberian Peninsula during the Roman Empire, showing the sampling sites of Pax Julia (Beja) and São Pedro (Fronteira).

(second century AD) from the Alentejo region of southern Portugal were collected for analysis. The sampling sites were selected in view of their strategic locations near major Roman trade and cultural routes, the Fronteira site being in the immediate proximity of the Roman main road connecting Lusitania's capital, Emerita Augusta (Merida), to Olisipo (Lisbon), while the Beja site is close to the Iberian Pyrite Belt (IPB), an important mining area, massive sulphide ore deposits of which have been exploited since Roman times (Leistel et al. 1998). Most samples show visible signs of corrosion phenomena on their surfaces, with the development of an opaque and flaky patina. The main component of Roman glass is siliceous sand $\left(\mathrm{SiO}_{2}\right)$, known as the glass former, which is usually extracted from fluvial or beach sedimentary sand deposits (Aerts et al. 2003; Freestone 2006; Silvestri et al. 2006). Soda was added as a modifier to lower the melting temperature of the silica, and the most common source was natron, a complex, polyphase evaporitic deposit rich in $\mathrm{Na}$ carbonates, found in Upper Egypt (Freestone 2006; Shortland et al. 2006). Other components included phases containing transition element chromophore ions $\left(\mathrm{Fe}^{2+}, \mathrm{Fe}^{3+}, \mathrm{Co}^{2+}, \mathrm{Mn}^{3+}, \mathrm{Cu}^{+}\right.$and $\left.\mathrm{Cu}^{2+}\right)$ and elements such as $\mathrm{Mn}$ and $\mathrm{Sb}$, present either as impurities in the sand former or intentionally added to provide the glass with a finished colouring effect (Arletti et al. 2006; Veiga and Figuereido 2006; Lahil et al. 2008, 2010; Verità et al. 2008; Foster and Jackson 2009). Quantitative, multi-elemental glass compositional analyses (major, minor and trace elements) have been used to provide information on glass-making technology, sources of raw materials and corrosion mechanisms, as well as providing evidence contributing to the identification of glass production centres in antiquity (Freestone 2005, 2006). A wealth of 
studies have dealt with the characterization of glass objects and their corrosion features in various parts (and time periods) of the Roman Empire, from Jordan (Janssens et al. 1996; Aerts et al. 1999) to Turkey (Degryse et al. 2005; Schreiner et al. 2007), Hungary (Borbély-Kiss et al. 1994), Albania (Boschetti et al. 2008), Italy (Mirti et al. 1993; Dal Bianco et al. 2004; Silvestri et al. 2005, 2008; Climent-Font et al. 2008), France (Weber et al. 2002; Fredrickx et al. 2004), Germany (Aerts et al. 2003; Fredrickx et al. 2004), Belgium and the Netherlands (Aerts et al. 2003; Huisman et al. 2008) and the United Kingdom (Cox and Ford 1993; Baxter et al. 2005; Paynter 2006; Foster and Jackson 2009). On the contrary, analytical data on the bulk chemical composition and on corrosion features of vitreous artefacts from the Iberian Peninsula, both from pre-Roman (Rincón 1993; García-Heras et al. 2005) and Roman (Rius et al. 1989; Gomez-Tubio et al. 2006) times, is remarkably scarce. In fact, apart from an undetailed statement made by the Roman historian Pliny the Elder, in his treatise Naturalis historia, concerning the existence of glass production centres in the westernmost regions of the Empire (Baxter et al. 2005; Silvestri et al. 2006), archaeometric evidence for primary Roman glass production centres in the Iberian Peninsula as a whole is still somewhat scarce (Jimenez et al. 2008; Dias da Cruz 2009). Even more so, compositional studies on Roman glass from the Portuguese south-western section of the peninsula, which could shed light on glass-making technology and production in such an economically important region of the Empire, is - to the authors' knowledge-missing altogether. The aim of the present study is, therefore, twofold: (a) to chemically characterize, for the first time, glass samples from the Fronteira and Beja sites in terms of their major, minor and trace element composition, with a view to identifying their different components (former, fluxes, stabilizers, colouring, decolouring and opacifier agents) and their possible correlations with age, raw material provenance and production techniques; and (b) to obtain a better understanding of the complex chemical processes responsible for the development of the multilayered corrosion patinas in the historical glasses examined-this information is of extreme relevance to glass conservators in the selection of the most appropriate restoration strategy for archaeological glass (Mäder and Neelmeijer 2004).

To achieve this aim, a multi-analytical spectroscopic methodology has been adopted, combining backscattered scanning electron microscopy and energy-dispersive spectroscopy (BSEMEDS), external proton-induced X-ray emission/proton-induced gamma emission spectroscopy (PIXE/PIGE) and confocal synchrotron $\mu$-X-ray fluorescence spectroscopy (SR- $\mu$ XRF). The spatial resolution and phase contrast of BSEM imaging was used to investigate the microtexture of the corrosion layers, while the EDS system provided 2D major elements maps and linescan profiles spanning the pristine glass-weathering patinas interface (Janssens et al. 1996; Messiga and Riccardi 2006; Genga et al. 2008; Huisman et al. 2008; Lahil et al. 2010). The higher sensitivity of PIXE/PIGE was used to provide major, minor and trace element data from the bulk glass. Geochemical associations were investigated, including those involving transition element ions $(\mathrm{Zr}, \mathrm{Ti})$ that could be used as discriminants for assessing the source of the silica sand raw material (Aerts et al. 2003). PIXE/PIGE sensitivity usually reaches a few micrograms per gram for transition metals, and several hundreds of micrograms per gram for the major elements, which has been found appropriate to address most provenance studies (Calligaro 2008; Carmona et al. 2010). One of the major assets of PIXE in cultural heritage applications is its non-destructive nature. The depth of proton penetration within glass is limited, however, to no more than a few microns (the typical maximum depth of analysis in glass for a beam of $2.5 \mathrm{MeV}$ is $30-35 \mu \mathrm{m}$; Kuisma-Kursula 2000). As the thickness of corrosion patinas in archaeological glass often exceeds several tens of micrometres, non-destructive, direct PIXE analysis of the surface of glass artefacts without sample treatment would provide compositional data limited to the outer 
corroded surface, therefore yielding unreliable results with regards to bulk glass leachable elements such as $\mathrm{Na}$ (or K). To overcome this problem, PIXE/PIGE depth profiling analysis for $\mathrm{Na}$ could be performed by sequentially varying ion beam parameters such as the energy sequence and the ion beam energy, and by increasing the measuring times (Climent-Font et al. 2008). This non-destructive methodological approach is, however, rather time- and cost-consuming and does not appear to be suitable for performing serial measurements on large sets of objects. In this study, PIXE/PIGE was therefore performed mainly on polished sections of glasses cut from resin-embedded samples. This experimental approach, although microdestructive (as the glass fragments embedded in the resin blocks cannot be recovered), has been proven to provide the best cost-benefit ratio (Climent-Font et al. 2008). While the PIXE/PIGE configuration under the helium flux used was suitable for analysing important light glass elemental components such as $\mathrm{Na}$, rare earth elements, such as yttrium, are seldom measurable by PIXE, because of the low production yield of their $\mathrm{K}$ line and the overlap of the $\mathrm{L}$ lines with the strong $\mathrm{K}$ lines of other constituents of glass. To complement trace element results and geochemical trends from PIXE/ PIGE, therefore, SR- $\mu$ XRF was used to provide additional data on trace element concentration gradients between bulk unweathered glass and corrosion layers through $2 \mathrm{D}$ elemental maps and linescan profiles. Furthermore, the reduced beam size of SR- $\mu$ XRF, as opposed to PIXE, provides better results when used to produce elemental maps. On the other hand, the ANKA Synchrotron FLUO beamline was not operated under the helium flux in the same way as for PIXE/PIGE, and therefore was unsuitable for light elements analysis such as $\mathrm{Na}$.

\section{EXPERIMENTAL}

Thirty-seven samples from the São Pedro site (Fronteira) and nine glass fragments from the Beja site were investigated. A preliminary visual examination using a LEICA M250C stereomicroscope was performed to detect macroscopical properties such as colour and the presence and nature of corrosion features (pitting, iridescence and corrosion layers). Prior to the chemical analyses, the samples were vacuum impregnated with epoxy resin and embedded into resin blocks, which were subsequently cut to expose a cross-section perpendicular to corroded glass surfaces and then polished using up to $1 \mu \mathrm{m}$ grain-sized final diamond paste.

The PIXE/PIGE analyses were carried out using the external beamline at the AGLAE facility of the Laboratoire du Centre de Recherche et de Restauration des Musées de France, Louvre Museum, Paris. The AGLAE beamline is generated by a Pelletron model accelerator, equipped with a $0.1 \mu \mathrm{m}$ thick $\mathrm{Si}_{3} \mathrm{~N}_{4}$ exit window. The PIXE/PIGE set-up combines four detection channels, two X-ray detectors for PIXE, one HPGe detector for PIGE and a surface barrier detector for RBS (Calligaro 2008). The first $\mathrm{Si}(\mathrm{Li})$ detector is operated in a helium stream to measure elements from $\mathrm{Na}$ to $\mathrm{Fe}$ (the main constituents of the glass), while the second one, with a 50- $\mu \mathrm{m}$ aluminium foil to absorb the strong Si line emitted by the glass, is used to analyse only elements heavier than $\mathrm{Ca}$, mostly trace elements in the present case. The samples were irradiated under ambient atmosphere (He flux) with $3 \mathrm{MeV}$ protons, with an intensity of $5 \mathrm{nA}$ for 5-10 min. The beam was focused to a $40 \mu \mathrm{m}$ diameter on the sample placed $2 \mathrm{~mm}$ downstream of the $0.1 \mu \mathrm{m}$ thick $\mathrm{Si}_{3} \mathrm{~N}_{4}$ exit membrane. Careful examination of the glass surface did not show any visible damage induced by the particle beams. The PIXE spectra were processed using the GUPIX spectrum analysis and quantification software, with the assumption that the targets were thick and homogeneous and that all elements were in oxide form (Maxwell et al. 1995). The PIXE/PIGE analyses were carried out mainly in 'scanning' mode to account for glass heterogeneity (GomezTubio et al. 2006; Grassi et al. 2007). The elements detected were $\mathrm{Na}, \mathrm{Mg}, \mathrm{Al}, \mathrm{Si}, \mathrm{P}, \mathrm{S}, \mathrm{Cl}, \mathrm{Ar}, \mathrm{K}$, 
Ca, Ti, V, Cr, Mn, Fe, Co, Ni, Cu, Zn, Ga, As, Br, Rb, Sr, Zr, Sn, Sb, Ba and Pb. The instrumental set-up allows the analysis of cultural heritage samples at atmospheric pressure under no vacuum and without prior coating, thus reducing to a minimum the risk of damage to the artefacts.

Selected polished blocks were sputter-coated with carbon and investigated under an HITACHI S3700N VP-SEM, interfaced with a Quantax EDS microanalysis system. The Quantax system was equipped with a Bruker AXS X-Flash ${ }^{\circledR}$ Silicon Drift Detector (129 eV Spectral Resolution at $\mathrm{FWHM}-\mathrm{Mn} \mathrm{K}_{\alpha}$ ). Standardless PB/ZAF quantitative elemental analysis was performed using the Bruker ESPRIT software. The operating conditions for EDS analysis were as follows: backscattered electron mode (BSEM), $20 \mathrm{kV}$ accelerating voltage, $10 \mathrm{~mm}$ working distance, $120 \mu \mathrm{A}$ emission current. The detection limits with this configuration for major elements $(>\mathrm{Na})$ were in the order of $0.1 \mathrm{wt} \%$. For SR- $\mu \mathrm{XRF}$, the synchrotron $\mu-\mathrm{XRF}$ at the Fluo Beamline of the ANKA synchrotron radiation facility in the Karlsruhe Institute of Technology, Germany was used. The energy of the synchrotron monochromatic radiation for the glass analyses was set at $20 \mathrm{keV}$, with a beam diameter of $2 \times 5 \mu \mathrm{m}$ and a measuring time between 2 and $10 \mathrm{~s}$. The region of the sample measured by the X-ray microprobe was simultaneously investigated using an optical microscope. With this configuration, the detection limits are in the range of $\mathrm{ng} \mathrm{g}^{-1}$ to $\mu \mathrm{g} \mathrm{g}^{-1}$ (depending on the nature of the glass matrix). The $\mathrm{Si}(\mathrm{Li})$ detector employed had a resolution of $133 \mathrm{eV}(\mathrm{FWHM})$ at $5.9 \mathrm{keV}$. Data handling was performed using the PyMca software (Solé et al. 2007).

\section{RESULTS AND DISCUSSION}

Apart from the differences in colour, the glass fragments from the two sites appear to be macroscopically similar (Figs 2 (a) and 2 (b)). The Beja glasses are either colourless or yellowish in colour. Pitting is evident (Fig. 2 (a)). The glass samples are coated by multilayered corrosion patinas made up of fairly uniform iridescent lamellae: in some cases, the laminated structure makes the glass surfaces fragile and prone to exfoliation (Fig. 2 (b)). However, no strong fragmentation ('sugaring' if glass is fragmented into pieces $<0.1 \mathrm{~cm}$ ) is present as, on the contrary, is often the case with medieval glass and/or with Roman colourless glasses that have experienced burial under extreme waterlogged conditions (Silvestri et al. 2005; Huisman et al. 2008). The São Pedro glasses are variously coloured (blue, green, blue-green [aqua] and pink).

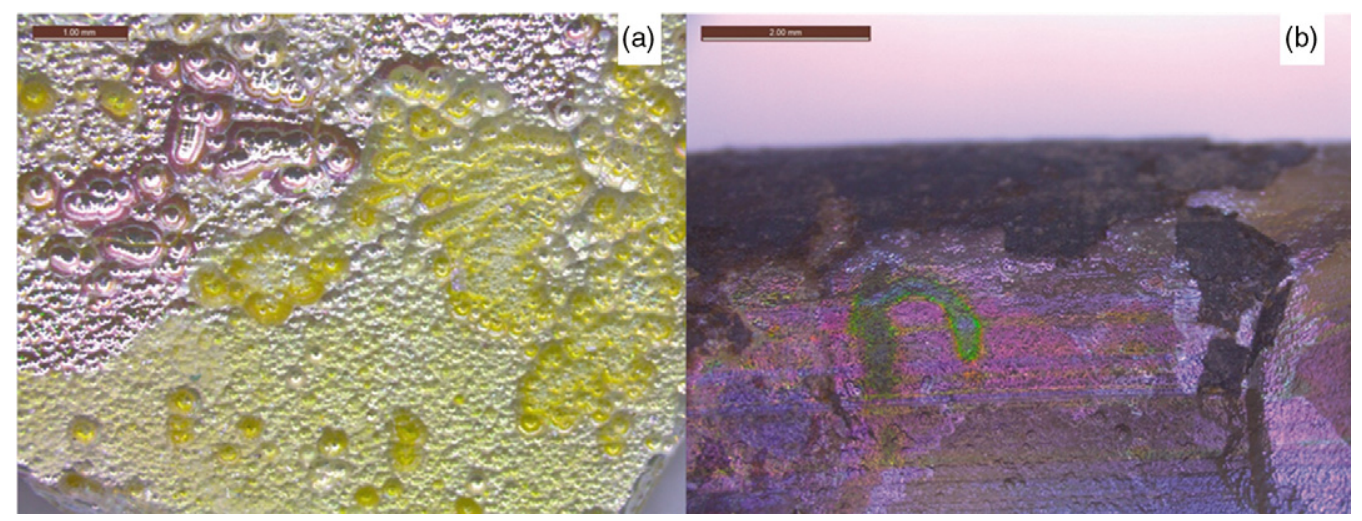

Figure 2 Glass fragments: (a) Beja glass, showing strong surface pitting; (b) Fronteira glass, showing the surface development of iridescent lamellae. 
Corrosion pitting is intense and coating by iridescent lamellae, which imparts a surface rainbowlike effect, is again evident (Fig. 2 (b)).

\section{Pristine bulk glass}

Pristine areas from the Beja and Fronteira glass samples display similar bulk chemical compositions by PIXE/PIGE (Table 1 and the $\mathrm{Na}_{2} \mathrm{O}-\mathrm{CaO}-\left(\mathrm{K}_{2} \mathrm{O}+\mathrm{MgO}\right)$ ternary diagrams in Fig. 3). The glasses belong to the soda-silica-lime type with mean $\mathrm{SiO}_{2}$ contents for the Beja and Fronteira samples, respectively, of $72.01 \mathrm{wt} \%$ and $67.49 \mathrm{wt} \%$, mean $\mathrm{Na}_{2} \mathrm{O}$ contents of $14.77 \mathrm{wt} \%$ and $18.67 \mathrm{wt} \%$, and mean $\mathrm{CaO}$ contents of 6.58 and $6.30 \mathrm{wt} \%$ (Table 1). The mean $\mathrm{K}_{2} \mathrm{O}$ content is $0.65 \mathrm{wt} \%$ for Beja (with only one sample exceeding $1.5 \mathrm{wt} \%$ ) and $0.43 \mathrm{wt} \%$ for Fronteira; similarly, the mean $\mathrm{MgO}$ concentrations never exceed $1.5 \mathrm{wt} \%$ at either site, except in the same sample as for the $\mathrm{K}_{2} \mathrm{O}$ content (means of $0.79 \mathrm{wt} \%$ for Beja and $0.95 \mathrm{wt} \%$ for Fronteira). According to their $\mathrm{Mg}$ and $\mathrm{K}$ oxide contents, the soda-silica-lime ancient glasses have been subdivided into two subtypes; that is, into glasses containing less and/or more than $1.5 \%$ of each oxide (Sayre and Smith 1961). It is widely accepted that 'high-magnesia' glass indicates the use of plant ashes as flux (common in Bronze Age glass as well as in Islamic and Venetian medieval vitreous artefacts) while the 'low-magnesia' variety is typical of glasses made using natron as the source of soda flux, as is the case with the vast majority of Roman glass objects (Henderson et al. 2005; Shortland et al. 2006; Climent-Font et al. 2008). The low-Mg, low-K concentrations revealed by the bulk PIXE analyses of the Beja and Fronteira glasses therefore confirm a typical Roman glass production technology for the samples investigated (Table 1).

Concentration plots of $\mathrm{Si}, \mathrm{Ca}$ and $\mathrm{Al}$ against $\mathrm{Na}$, drawn from spot analyses in unweathered inner glass regions, show that while the $\mathrm{Si}, \mathrm{Ca}$ and $\mathrm{Al}$ concentrations remain fairly constant across the whole analysed region of the glass, the Na concentrations are characterized by a much wider scatter (Fig. 4 (a)). This seems to suggest that Na leaching processes are active even in apparently unweathered regions of the glass at a distance of several millimetres from the outer corroded surface. A similar behaviour is displayed by $\mathrm{Cl}$, the concentrations of which-as is the case for $\mathrm{Na}$ - display a wide range of values, which indicates that this element too appears to have been subjected to intense leaching, even in core regions of the glass fragments. The presence of $\mathrm{Cl}$ as a primary glass component is not unexpected, bearing in mind that this element is commonly associated with sodium in the original natron source (Freestone 2006). When plotting the concentrations of minor elements, it can be seen that Fe and Ti display a common behaviour (Fig. 4 (b)). In natural high-quartz sands-in other words, those typically used for glassmaking-minor elements can be concentrated in heavy minerals, commonly used as tracers in geological research. The observed Fe-Ti correlation may be explained by considering that these two elements are often associated in ilmenite $\left(\mathrm{FeTiO}_{3}\right)$, a common heavy mineral constituent of fluvial sands used as glass former. Other heavy minerals such as iron oxide minerals, hematite $\left(\mathrm{Fe}_{2} \mathrm{O}_{3}\right)$ and magnetite $\left(\mathrm{Fe}_{3} \mathrm{O}_{4}\right)$ can also be found selectively enriched together with $\mathrm{Ti}$ oxides $\left(\mathrm{TiO}_{2}\right.$ : rutile and/or its polymorph brookite) in fluvial sand placer deposits due to their similar sedimentation behaviour (Patyk-Kara et al. 2001). In analogy with Fe, Ti shows also a linear correlation with $\mathrm{Zr}$ (Fig. 4 (c)), which is again to be expected, as sand grains of the heavy mineral zircon $\left(\mathrm{ZrSiO}_{4}\right)$ are also selectively deposited together with ilmenite grains as accessory minerals in fluvial sedimentary deposits (Folk 1980). In fact, given the already mentioned fairly constant composition of Roman glass, some authors (Aerts et al. 2003) have used zirconium and titanium contents in glass to distinguish between different sources of silica sand in Roman and postRoman glasses. In archaeological terms, the positive $\mathrm{Fe}-\mathrm{Ti}$ and $\mathrm{Ti}-\mathrm{Zr}$ correlations, together with 


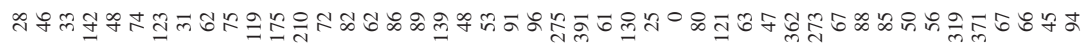

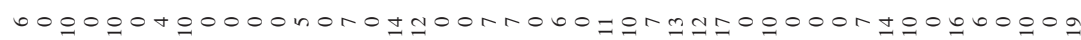

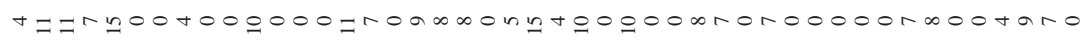

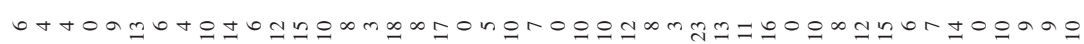
on

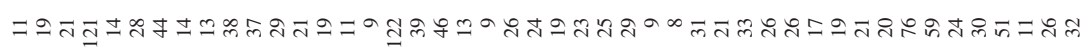

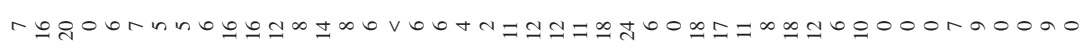

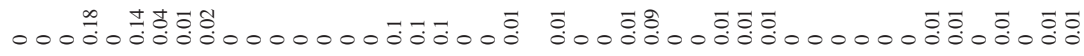

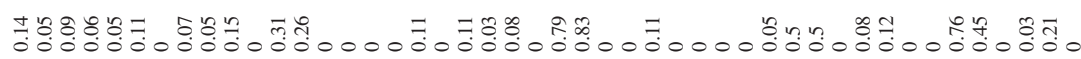

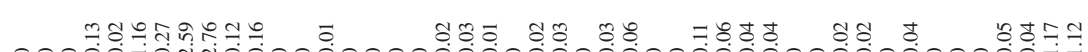

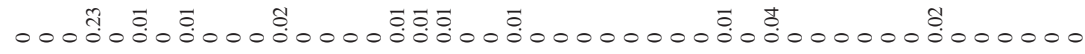

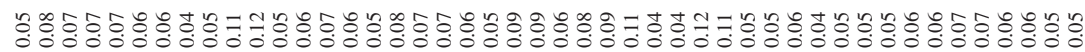
mे

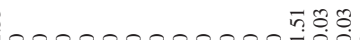
o

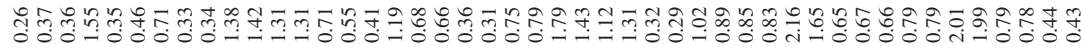

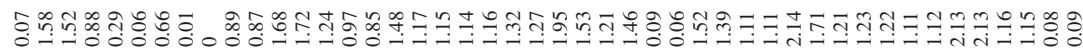

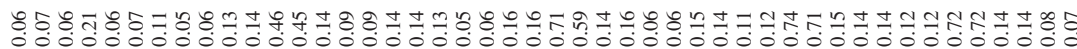

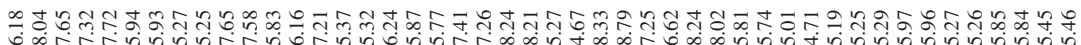

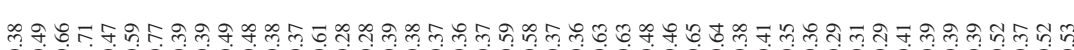

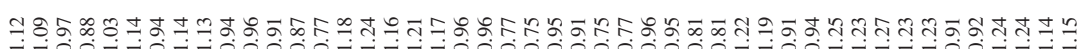

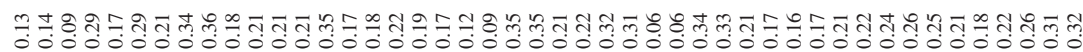
$0^{n}$

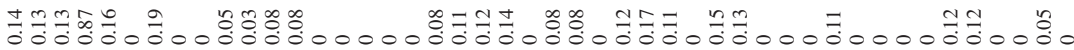

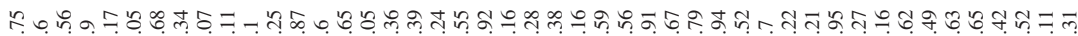

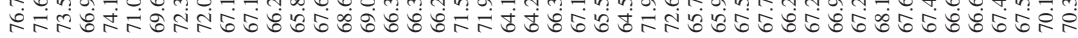

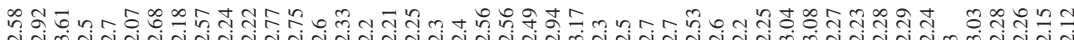

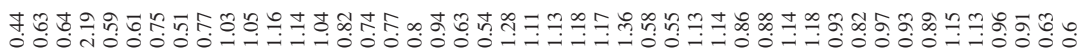

ڤ 든

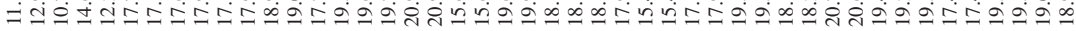

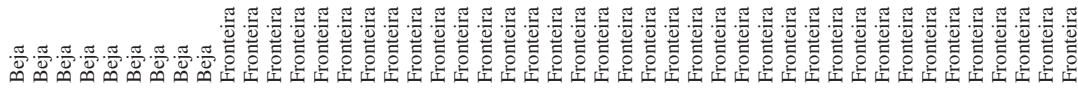

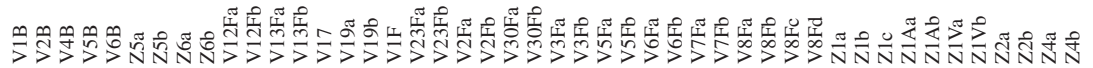



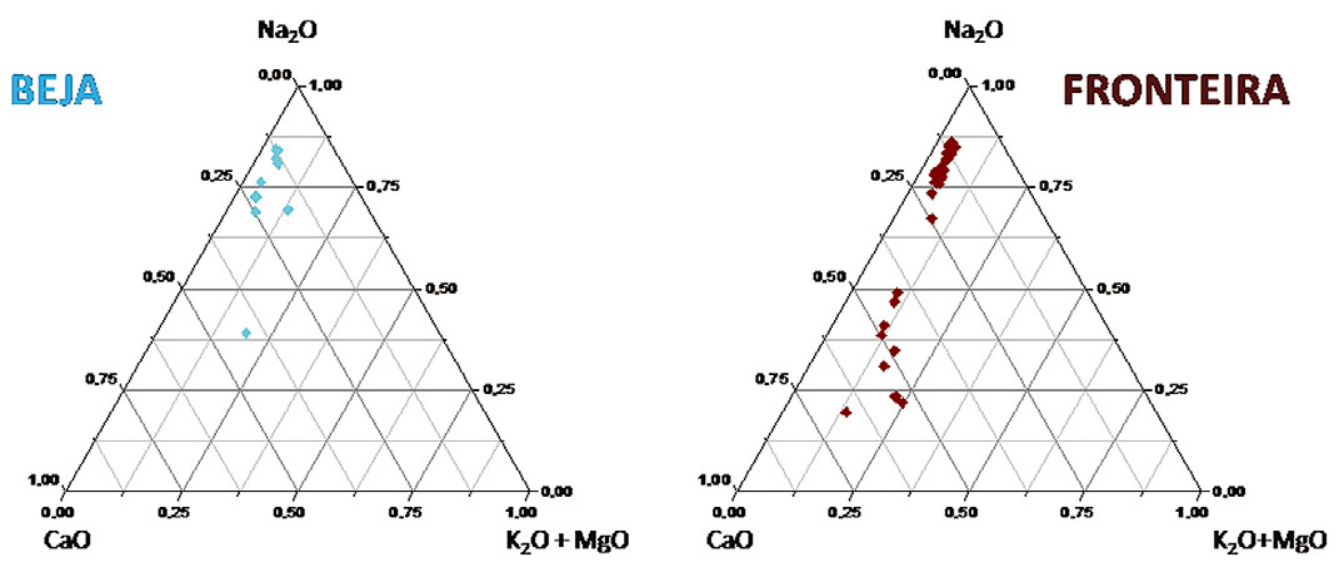

Figure 3 Pristine glass (PIXE/PIGE). $\mathrm{Na}_{2} \mathrm{O}-\mathrm{CaO}-\left(\mathrm{K}_{2} \mathrm{O}+\mathrm{MgO}\right)$ ternary diagrams for Beja and Fronteira glasses, showing a soda-silica-lime composition typical of Roman glasses.

their local geological availability, suggest not only that iron was present as an impurity in the raw material sand and was not added intentionally to modify the glass composition, but also that a common and local silica sand source is likely to have been used for the production of the glass objects examined in this study (Aerts et al. 2003). Moreover, the relatively high concentrations of $\mathrm{Zr}$ and Ti found in this study in some of the Fronteira glass samples may be used to constrain the age of these glasses to the second half of the fourth century AD. In fact, it is well known that at some point during that period, drastic changes in glass production occurred throughout the Empire: the changes involved stylistic and colour as well as compositional features, and included a significant increase in $\mathrm{Ti}$ and $\mathrm{Zr}$ elemental concentrations, which have been explained by the recycling of older glass and/or the use of less pure or unpurified raw materials becoming common practice in Roman glass-making industry (Aerts et al. 1999, 2003).

From the binary plots, it can be seen that Mn also shows a positive correlation with $\mathrm{Fe}$ (Fig. 4 (d)). This may be taken as further evidence for the interpretation of iron as an unwanted impurity in the original sandy raw material, as the addition of Mn compounds (pyrolusite in particular: $\mathrm{MnO}_{2}$ ) to the glass melt to act as decolouring agents was a well-established routine in Roman glass production (Freestone 2005). In the case of iron-containing glasses, the role of $\mathrm{Mn}^{\mathrm{IV}}$ was to oxidize $\mathrm{Fe}^{\mathrm{II}}$ to $\mathrm{Fe}^{\mathrm{III}}$, thereby reducing the unwanted green colouring effect due to the presence of the bivalent iron. The (almost) colourless glass thus produced could be used as such or be made available for the addition of a final colouring agent. To obtain a blue-coloured glass, for instance, $\mathrm{Cu}$ compounds were commonly used at this stage. The presence of a positive $\mathrm{Mn}-\mathrm{Cu}$ correlation in $\mathrm{Cu}$-rich blue glasses within the samples examined here (Fig. 4 (e)) is clear evidence of such a manufacturing process. Two samples from the Beja site, which display a white colour, show relatively high concentrations of antimony (Table 1). This could be explained by the intentional addition of antimony compounds, another class of glass opacifiers commonly used in Roman times, during the glass melting process. By reacting with the lime present as stabilizer in the melt, $\mathrm{Ca}$ antimonate precipitates, producing a whitish colour and acting as an opacifier in the final glass product (Lahil et al. 2008, 2010).

The higher sensitivity of the SR- $\mu$ XRF provided additional information on minor and trace element distributions that was not detectable using the previous techniques. Again, selected binary plots were used to highlight elemental distribution patterns. Common geochemical asso- 
(a)

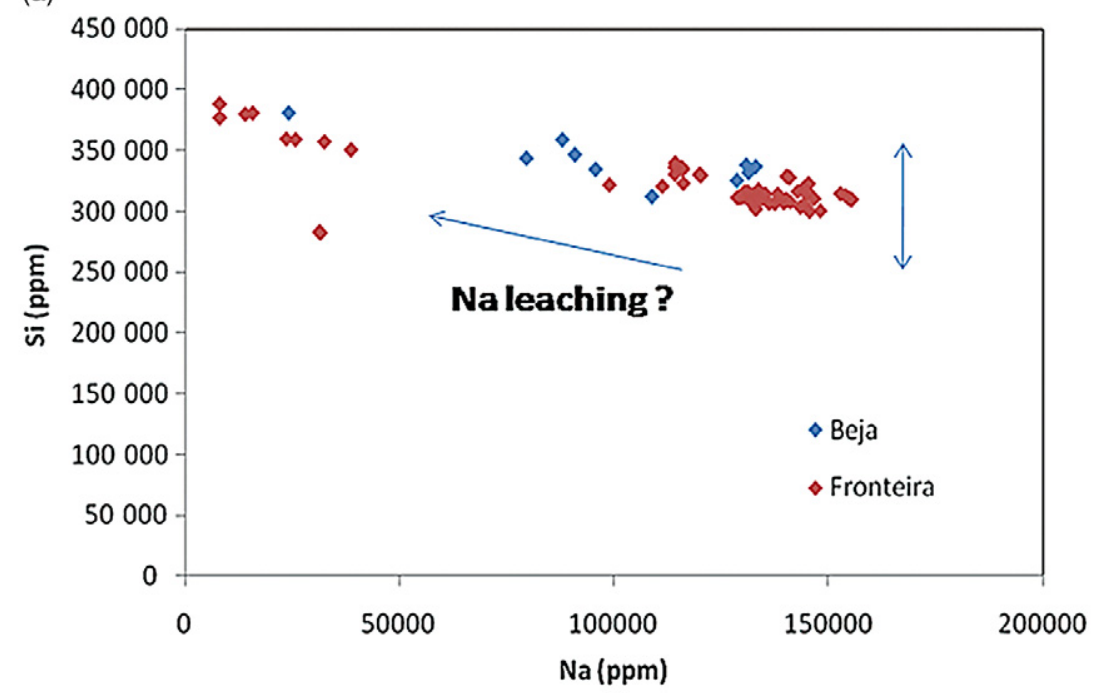

(b)

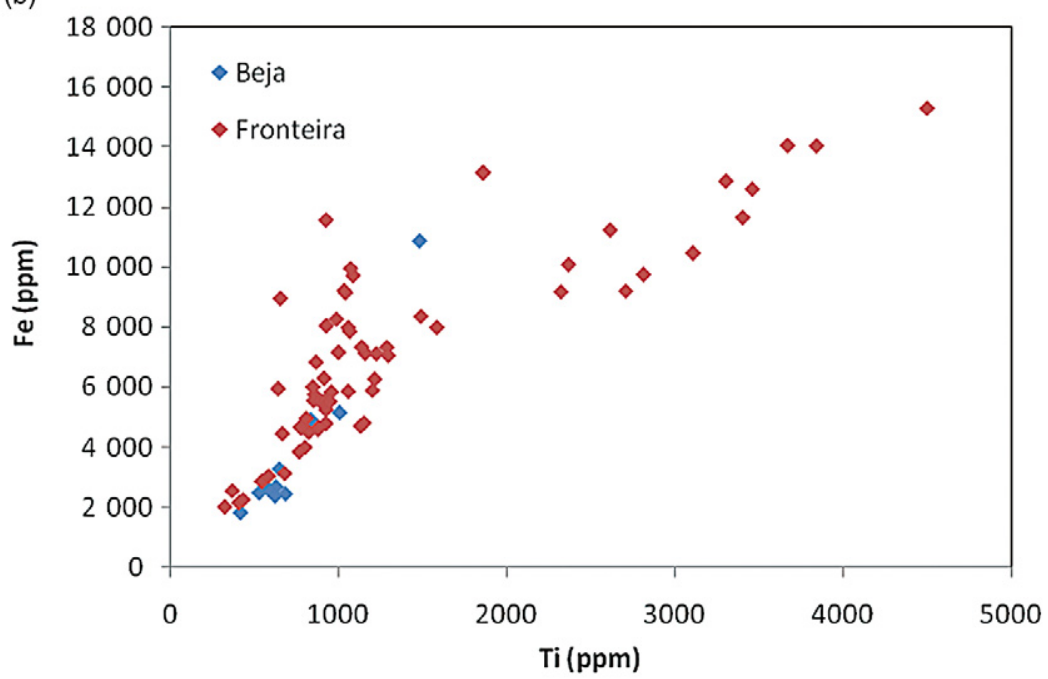

Figure 4 Pristine glass (PIXE/PIGE). Binary plots: (a) Si-Na (note the wide scatter of Na values); (b) Fe-Ti; (c) Zr-Ti; (d) $\mathrm{Mn}-\mathrm{Fe}$; (e) $\mathrm{Mn}-\mathrm{Cu}$. See the text for a full discussion.

ciations were identified in the pristine glass. For instance, strontium and yttrium show a strong positive correlation with Ca (Figs 5 (a) and 5 (b)). These elements are always associated with calcium-bearing minerals, because they can substitute this element in crystal structures due to their similar ionic radius. In the case of the glasses, $\mathrm{Y}$ was probably present as impurities in the Ca-rich lime stabilizers. The observed correlation between $\mathrm{Ca}$ and bromine was, on the other hand, unexpected (Fig. 5 (c)). In natural systems, bromine is usually bonded to alkaline metals in salts and is abundant (still as a trace element) in modern seawater, where it can reach concentrations up to $70 \mathrm{ppm}$. The positive $\mathrm{Br}-\mathrm{Ca}$ correlation highlighted by the SR- $\mu$ XRF investigation 


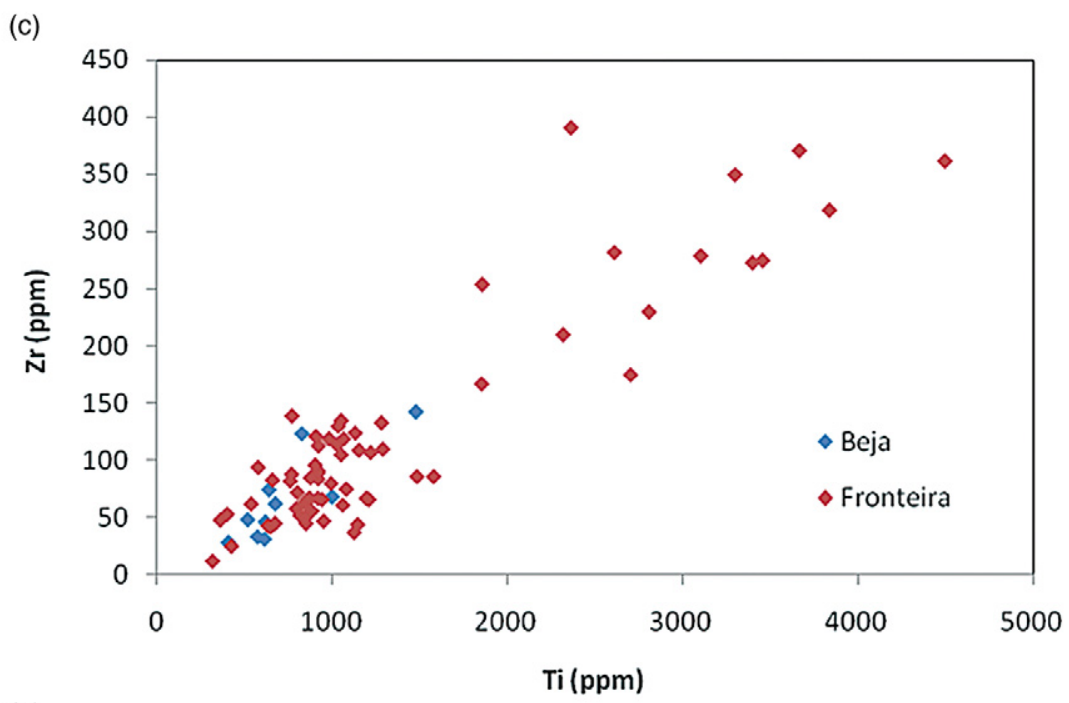

(d)

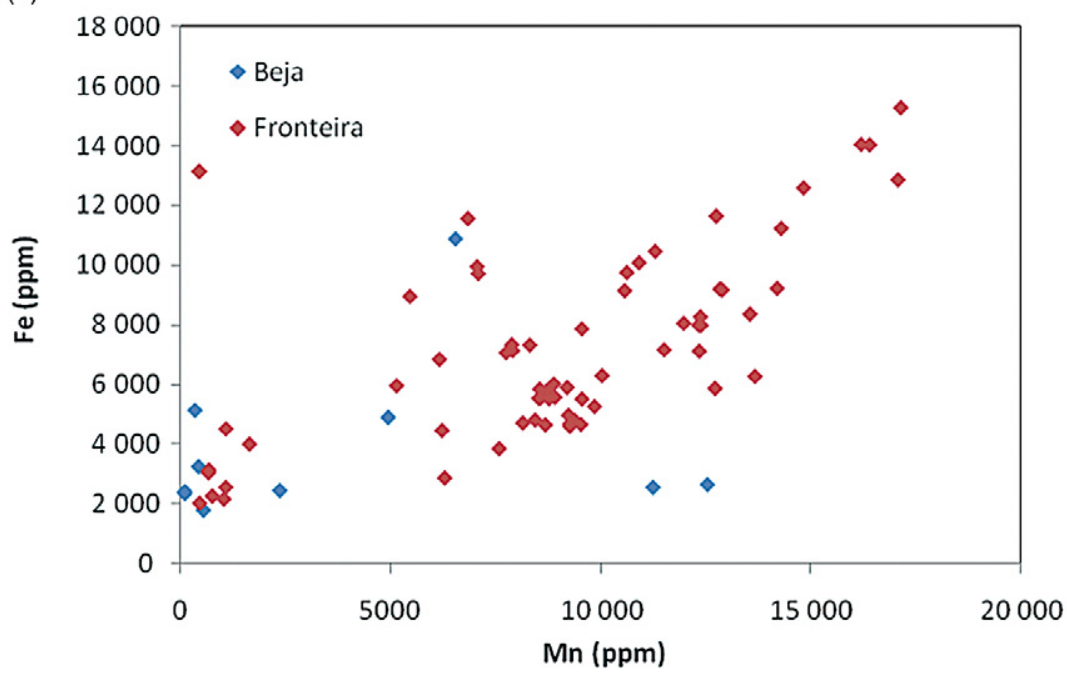

Figure 4 Continued.

of the glasses from Fronteira and Beja therefore suggests that the Ca compounds present in the glasses may not be derived from continental limestones, but from marine shells. This would be an important finding, as it provides a relatively quick analytical tool that could be used to complement other techniques, such as the use of Sr isotopes (Freestone et al. 2003) in identification of the sources of lime (continental versus marine), a topical issue in glass archaeology (Freestone 2006). The strong positive titanium-zirconium and titanium-niobium correlations (Figs 5 (d) and 5 (e)) can be explained by their presence as mineral impurities in the sandy raw material used for the glass former, by analogy with the $\mathrm{Ti}, \mathrm{Fe}$ and $\mathrm{Zr}$ correlations already revealed by PIXE. In fact, Nb-containing mineral grains of columbite $\left(\mathrm{FeNb}_{2} \mathrm{O}_{6}\right)$ are usually found selectively deposited together with zircon and ilmenite and other $\mathrm{Fe}-\mathrm{Ti}$ bearing oxide mineral 


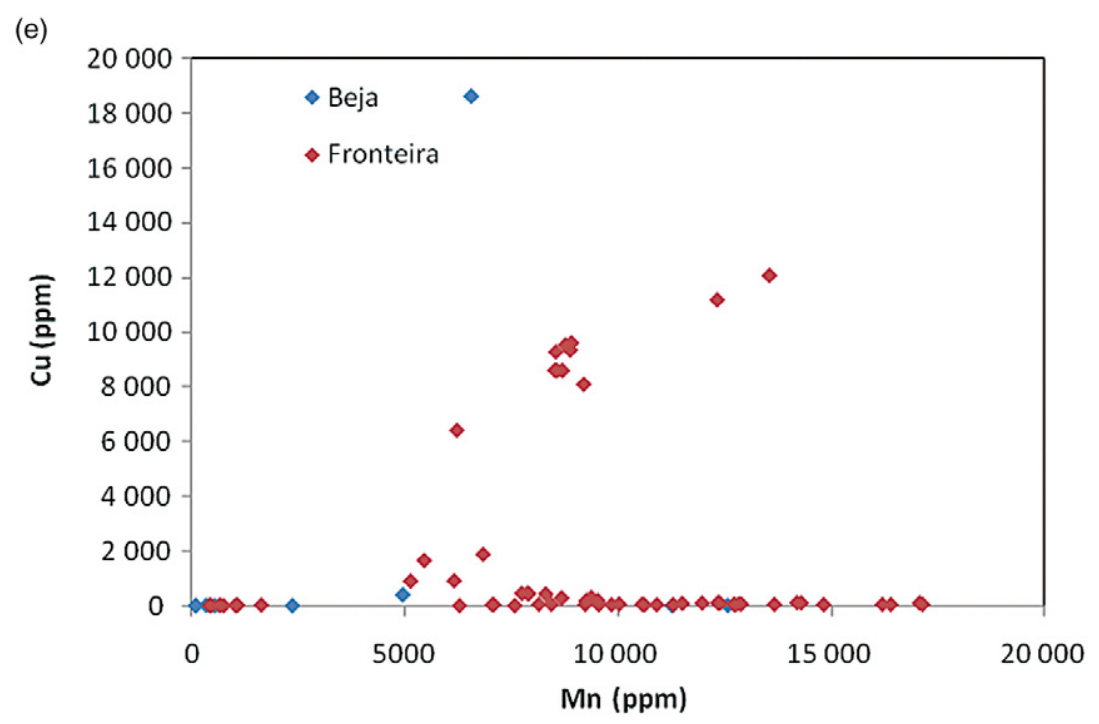

Figure 4 Continued.

oxides in sedimentary deposits as heavy mineral placers, due to their high resistance to erosional processes. Columbite-bearing mineral deposits are indeed quite common in granitic rocks and outcrops.

The SR- $\mu$ XRF elemental maps provide extra information on the distribution of trace elements. These analyses revealed that the glasses were not as homogeneous as suggested by the SEM + EDS maps. Elements such as zirconium or titanium, for instance, seem to be concentrated in small areas (Fig. 5 (f)). These regions may represent residual domains of refractory minerals. On the other hand, elements such as barium and lead are found concentrated at the surface of the glass (Fig. 5 (g)), probably due to precipitation of the first alteration phases, as barium and lead compounds. The correlation observed in this study between $\mathrm{Zr}$ and $\mathrm{Hf}$ (Fig. 5 (f)) has already been reported (but not explained) in other Roman glass studies (Smit et al. 2005; Wagner et al. 2008). These elements were probably present in the silica sand glass former as accessory refractory components. The close geochemical affinity between Hf and $\mathrm{Zr}$ is, in fact, a well-known phenomenon in geochemistry, as Hf can often be found substituting for $\mathrm{Zr}$ in zirconium-bearing minerals.

\section{Corrosion layers}

The BSEM imaging was particularly useful in the examination of the texture and composition of the glass corrosion layers. In most glass samples, three distinct regions could be recognized: (a) a core area of pristine, unweathered glass; (b) a multilayered corrosion patina; and (c) a precipitation crust, present at the outermost glass/burial environment interface. Under BSEM, the pristine glass appears rather homogeneous in all samples examined. The transition between pristine and corroded areas is in general fairly abrupt, but in some cases the boundary appears to be gradational. All corrosion layers display a finely laminated structure typical of archaeological glass recovered from damp soil horizons and made up of two distinct types showing either parallel and/or hemispherical layers (Fig. 6; see also Raw 1955; Cox and Ford 1993; Janssens 

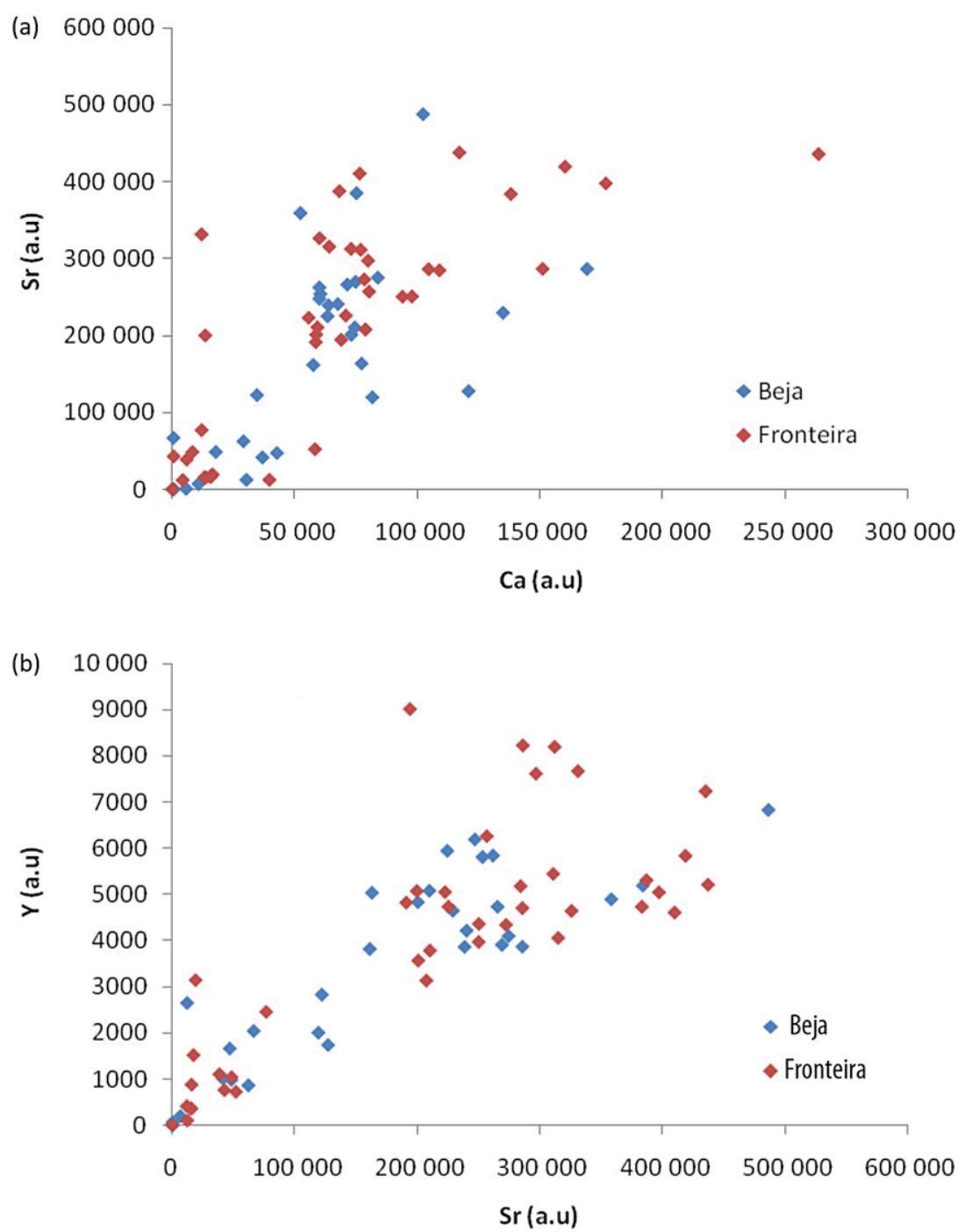

Figure 5 Binary plots $(a-e)$ and mapping $(f, g)$, showing common geochemical elemental associations and trace

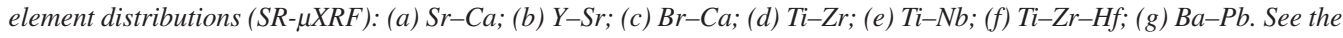
text for a full discussion.

et al. 1996). The reaction kinetics of the aqueous attack on silicate glasses that is responsible for the development of these corrosion features, in both archaeological findings and in natural geological materials such as basaltic glass, have been widely investigated and clarified through dissolution experimental data. They can be summarized as follows. The initial, diffusioncontrolled stage involves ion-exchange processes leading to alkali release into solution, while protons and water molecules enter the glass to produce a hydrated alkali-deficient gel layer; the gel layer grows until it reaches a constant thickness, at which point alkali, silica and other constituents are then extracted simultaneously via congruent dissolution. The silica dissolution is 
(c)

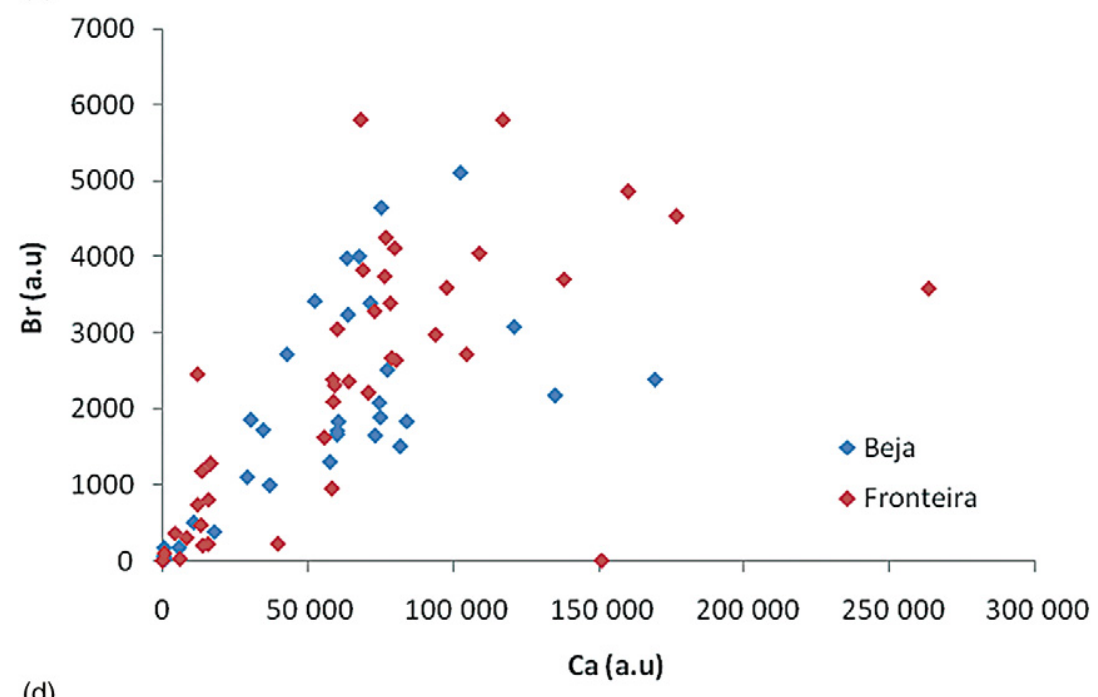

(d)

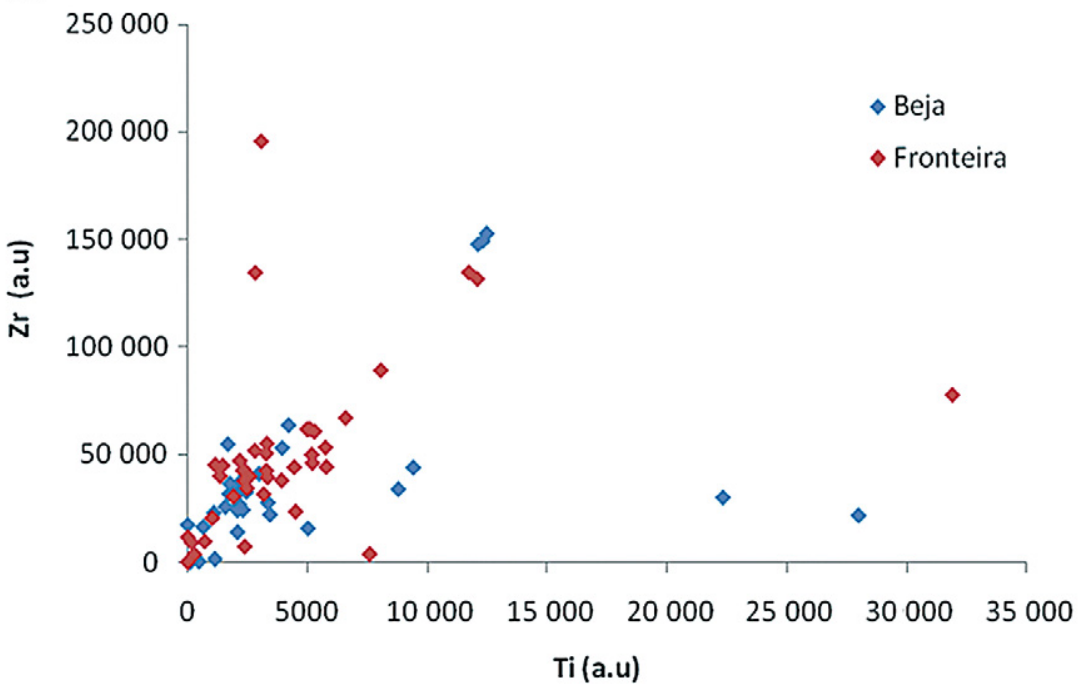

Figure 5 Continued.

$\mathrm{pH}$ dependent, with attacks by hydroxyl ions increasing above $\mathrm{pH} 9$ (Raw 1955). The subsequent precipitation of dissolution products on the surface of the samples as secondary phases depends on the solubility of the constituents' oxides, which in turn regulate the $\mathrm{pH}$ and concentration of the attacking solution at the reaction front. Cyclic reaction conditions results in the formation of the observed laminated structure. The development of the two different corrosion morphologies (parallel versus hemispherical) is related to differences in the progression of the advancing corrosion front: areas where the corrosion occurred gradually, with moisture not entering the glass through cracks or air bubbles, see the development of parallel layers, whereas the hemispherical layered morphology is the final morphological product, where the weathering attack has 


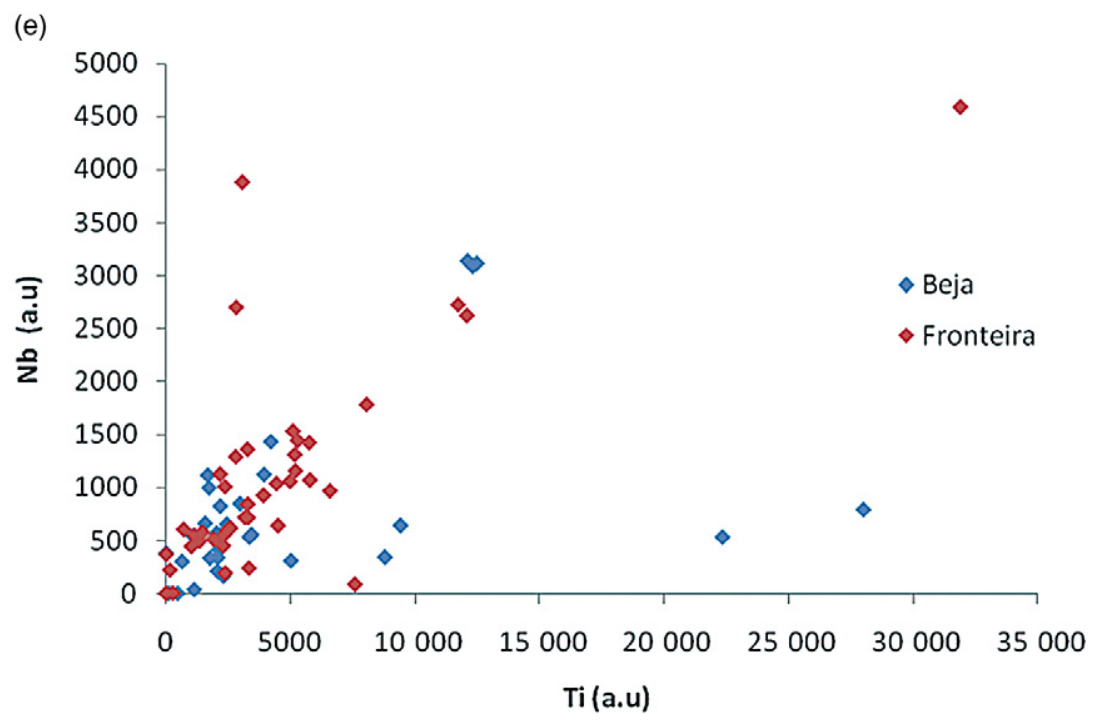

Figure 5 Continued.

progressed more rapidly at the location of glass irregularities such as air inclusions or embedded mineral particles (Cox and Ford 1993; Janssens et al. 1996). The thickness of the multilayered alteration in the Beja and Fronteira glasses ranges between 100 and $250 \mu \mathrm{m}$. These values are consistent with mean corrosion rates of about $0.1 \mu \mathrm{m}$ per year, which in turn are in line with data reported in the literature for natron-type Roman glasses buried under a soil cover (Janssens et al. 1996; Silvestri et al. 2005). Thicker corrosion layers have been reported on Roman glass objects exposed to harsher seawater burial conditions, such as those reported by Silvestri et al. (2005) on glass objects recovered from a 1800-year-old Roman sunken ship, found at the bottom of the Adriatic Sea, where alteration layers with thicknesses exceeding $900 \mu \mathrm{m}$ were found. On the contrary, the alteration patinas reported in the present study are more in line with weathering patterns found in archaeological glass buried in soil and under groundwater attack: even so, the absence of extreme disintegration features (the so-called 'sugaring' effect) suggests that the Fronteira and Beja glasses were not exposed to extreme waterlogged soil conditions during their period of burial (Huisman et al. 2008).

EDS point analysis data coupled with elemental linescan profiles shows that, compared to the pristine glass, the corrosion layers are generally characterized by depletion in $\mathrm{Na}, \mathrm{Ca}$ and $\mathrm{Si}$ in the following order of relevance: $\mathrm{Na}>\mathrm{Ca}>\mathrm{Si}$. These results are in line with published analytical data on elemental trends in corroded archaeological glass (Cox and Ford 1993; Sterpenich and Libourel 2001; Salviulo et al. 2004). Minor elements such as $\mathrm{Fe}, \mathrm{Mg}, \mathrm{Mn}$ and $\mathrm{Cl}$ also show a depletion profile when moving from the pristine glass towards the alteration patinas while, on the contrary, Al and K concentrations show a marked increase (Fig. 6 (a)). While the recorded Al enrichment in weathered layers can be readily explained by the lower mobility of this element, the $\mathrm{K}$ behaviour is somewhat anomalous, as the vast majority of studies of Roman (as well as medieval) glass samples have reported a marked decrease in the K content of the corrosion layers when compared with the concentrations of the same element in the pristine glass (Cox and Ford 1993; Janssens et al. 1996; Sterpenich and Libourel 2001; Salviulo et al. 2004; Genga et al. 


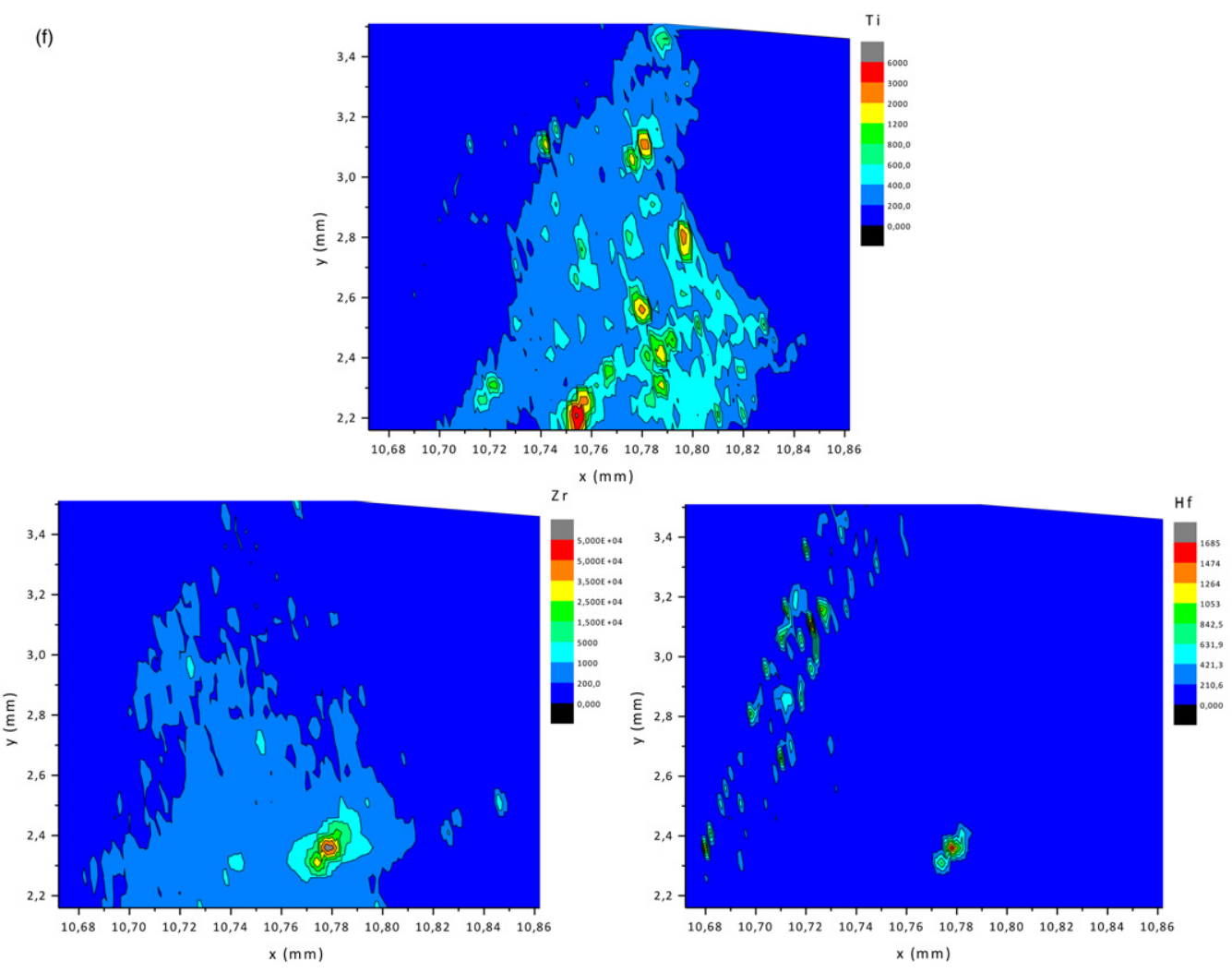

Figure 5 Continued.

2008; Huisman et al. 2008). In fact, the higher potassium leaching mobility (as opposed to that of $\mathrm{Na}$ ) has been advocated to explain the greater susceptibility to degradation of high-K medieval glass as compared to low-K Roman glass (Salviulo et al. 2004; Messiga and Riccardi 2006; Huisman et al. 2008). Only in rare cases has $\mathrm{K}$ enrichment in weathering layers from corroded Roman glass samples in both submerged (seawater influence) and buried (groundwater influence) environments been reported (Janssens et al. 1996; Aerts et al. 1999; Silvestri et al. 2005). In the case of submerged samples in a marine environment, these anomalously high $\mathrm{K}$ values have been explained by the high seawater concentrations of alkali elements (including K) which, according to experimental data on the dissolution of complex silicate glass in an alkali-rich solution, are responsible for lowering the diffusion of mobile ions through the porous weathering patina (Petit et al. 1990; Silvestri et al. 2005). If this process has indeed been active, however, one would expect to see simultaneous increases in both the $\mathrm{Na}$ and $\mathrm{K}$ concentrations: this does not occur in the samples examined in the present study (in which, in fact, the samples did not come into contact with seawater), where only $\mathrm{K}$ enrichment has been found in the corrosion layers. In any case, the above-mentioned limited diffusion model would not explain why, in the corrosion layers, we find higher concentrations of $\mathrm{K}$ with respect to those present in the pristine glass. An additional external soil source for $\mathrm{K}$ must then be envisaged. A possible explanation for the observed anomalous increase in the K content of the corrosion layers, that could be applied to the 

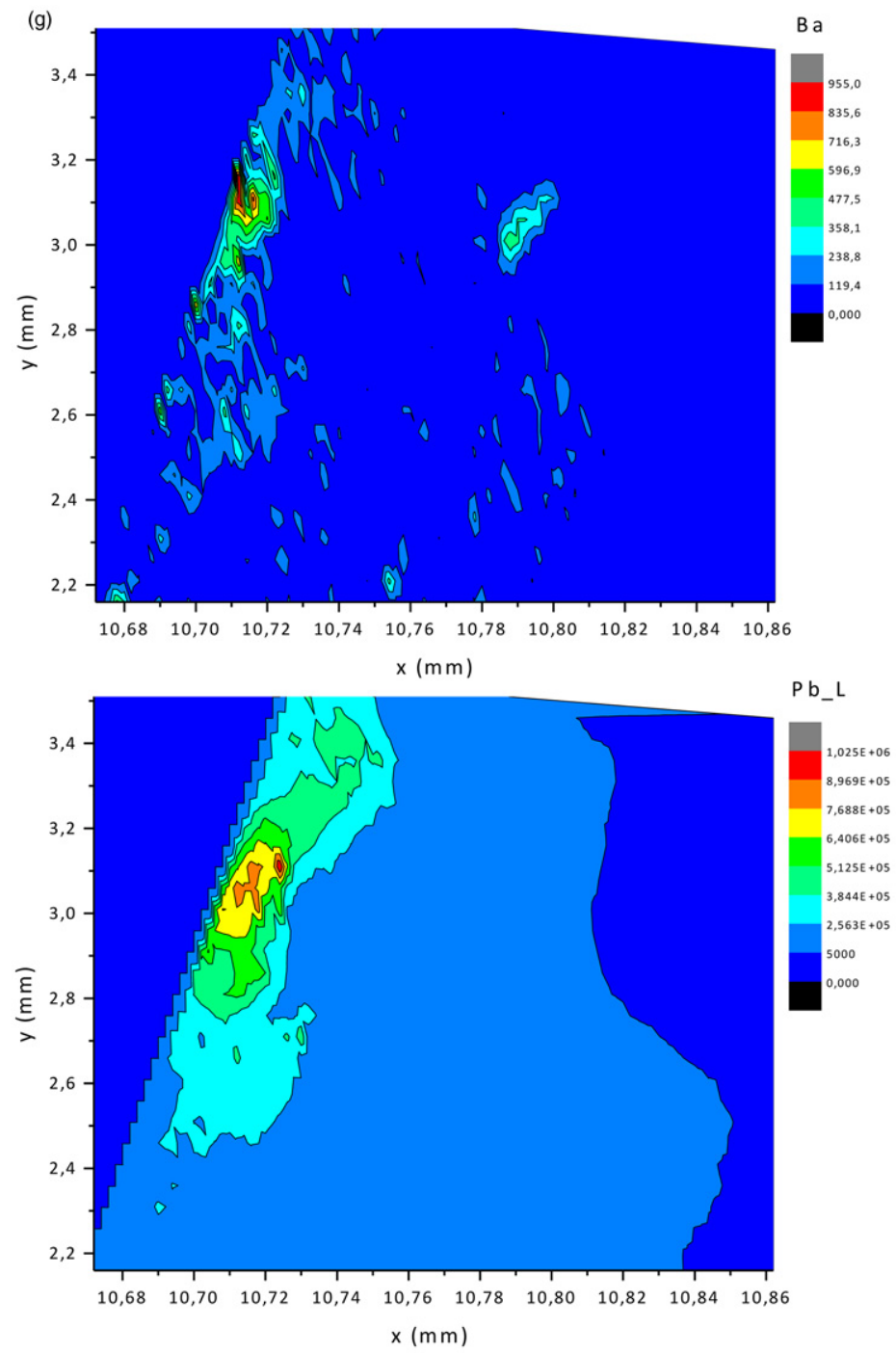

Figure 5 Continued.

current case (i.e., soil-buried glass samples) in particular, may be sought by taking into account evidence derived from soil geochemistry studies. K-bearing 2:1 clay minerals (one of the major constituents of soils) are known to play a key role in the soil K cycle (Aerts et al. 1999; Barré et al. 2008). It is well known that $\mathrm{K}$ absorption/release reactions involving potassium ions trapped in 2:1 clay mineral inter-layer sites are indeed common in soil environments. Such reactions are particularly common in weathering sequences affecting natural volcanic rocks, leading to the development of volcanic ash soils (Ndayiragije and Delvaux 2004). The production of locally K-enriched solutions within the soil hosting archaeological glass artefacts is therefore possible in particular in regions where K-bearing rocks are abundant. These solutions may play a dual role when they come into contact with the buried glass objects: (a) their high K concentration may 


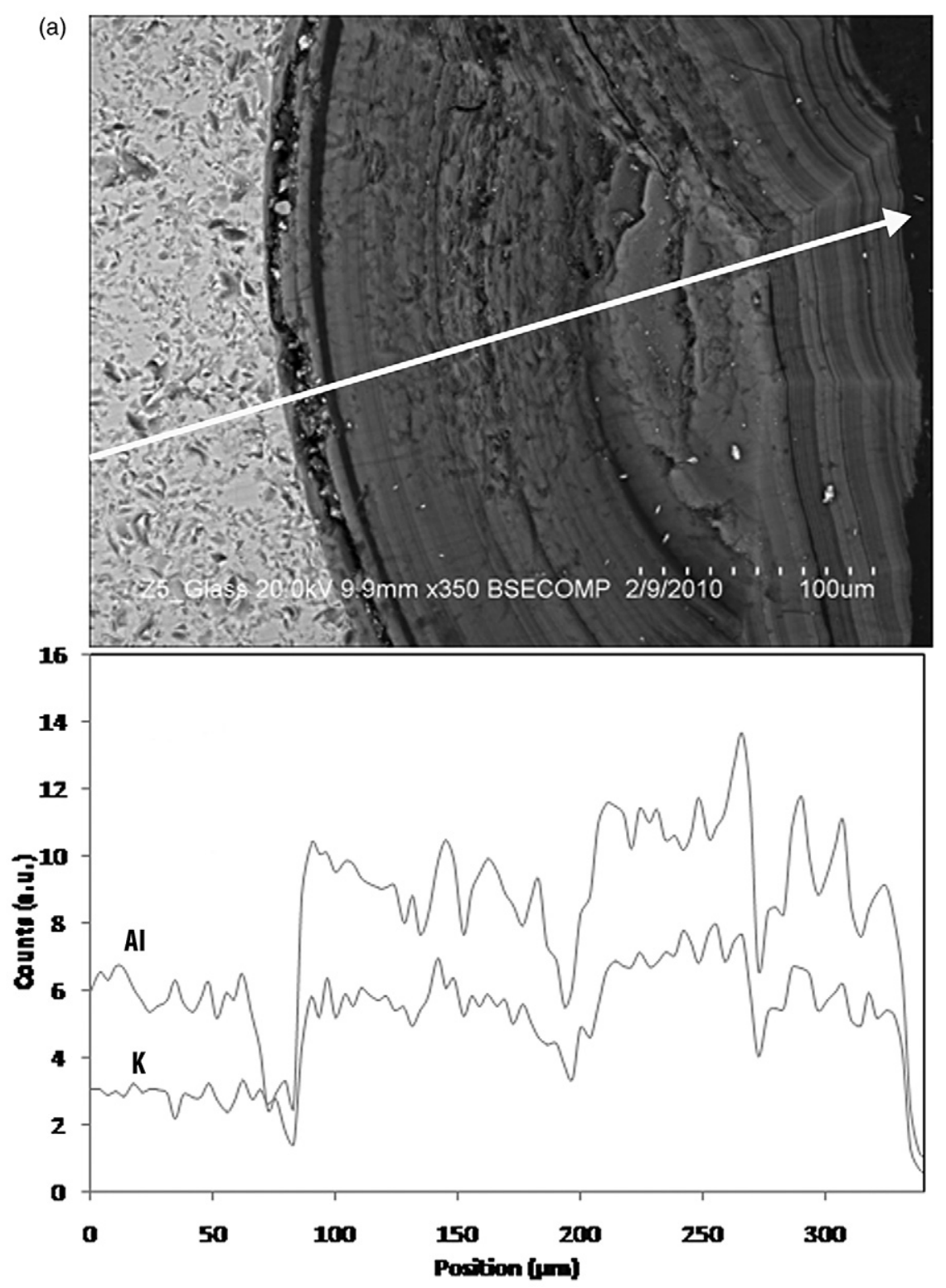

Figure 6 Elemental linescan profiles $(a, b)$ and mapping (c) through corrosion layers (BSEM $+E D S)$, showing: $(a) K$ and Al enrichment; (b) P enrichment within the outermost precipitation layer; (c) spatial distributions of $\mathrm{Na}, \mathrm{Si}, \mathrm{Al}$ and $F e$. See the text for a full discussion.

limit the mobility of this alkali from the glass, in accordance with the model proposed above for glass in submerged environments; (b) $\mathrm{K}$ ions may be absorbed into the growing corrosion patina and facilitate corrosion, as it is known that the presence of certain alkali ions (including $\mathrm{K}^{+}$) in soil aqueous solutions may be responsible for an increase in the dissolution rates in glass (Wickert et al. 1999). 


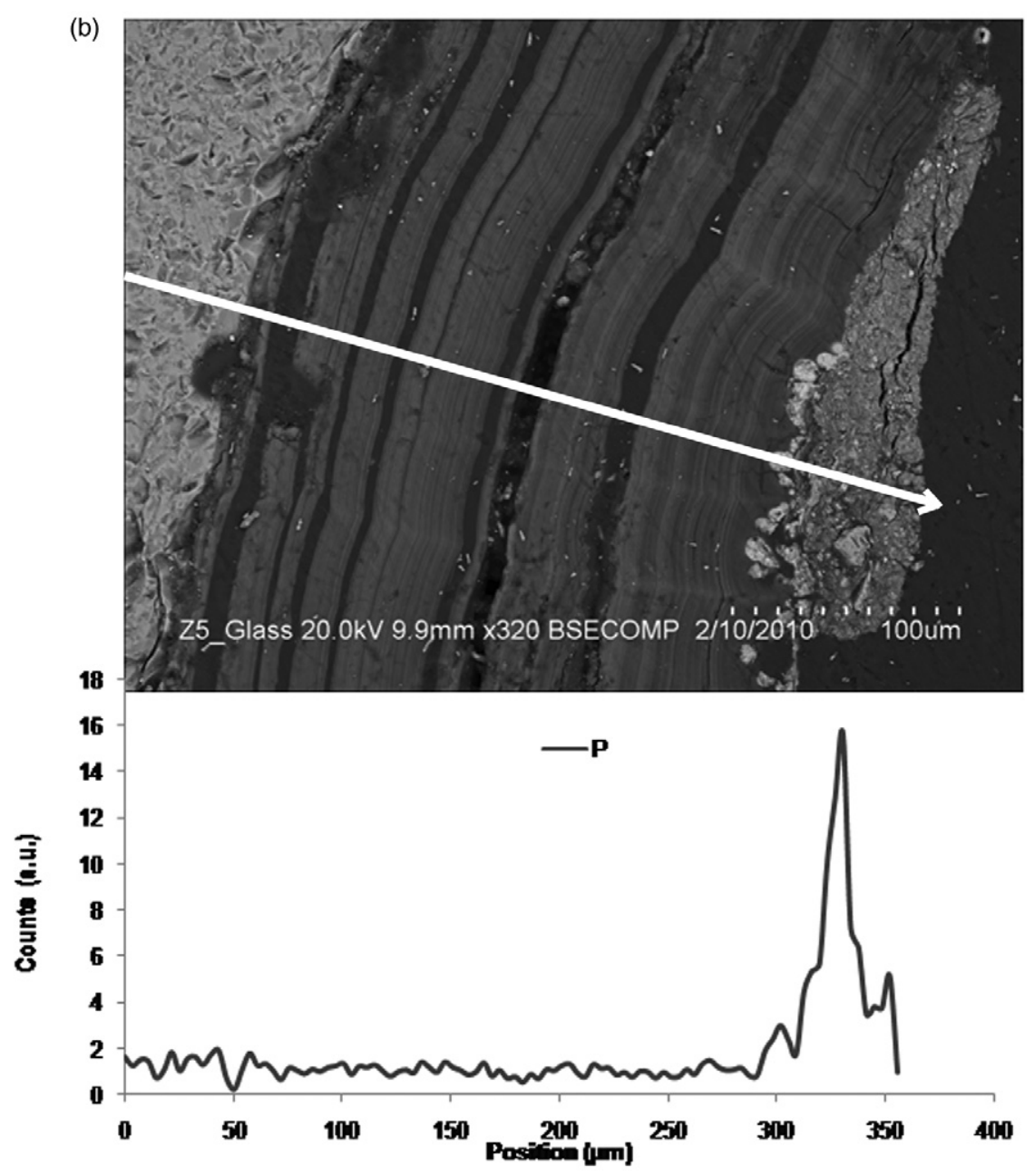

Figure 6 Continued.

The chemical composition of the outermost precipitation crust is quite heterogeneous (Fig. 6 (b)). It displays areas that are locally enriched (in a few cases, developing into a continuous layer) in $\mathrm{P}, \mathrm{S}, \mathrm{Ca}, \mathrm{Mn}, \mathrm{Al}, \mathrm{Ti}, \mathrm{Cr}$ and $\mathrm{Fe}$, reflecting localized precipitation of compounds in the form of phosphates, sulphates, oxides and carbonates. Although some of these constituents $(\mathrm{Ca}, \mathrm{Al}, \mathrm{Ti}$ and $\mathrm{Fe})$ are also present in detectable amounts in unaltered glass, others such as $\mathrm{P}$ appear to have entered into the crusts from the surrounding soil environment through groundwater solutions, which enter into the porous corrosion crust through microcracks and other surface defects (Cox and Ford 1993; Janssens et al. 1996). Both internal (glass composition, surface roughness and microcracks) and external (temperature, time, $\mathrm{pH}$, aqueous solution composition and soil composition) factors may be controlling these precipitation events. It is interesting to note that the presence of $\mathrm{P}_{2} \mathrm{O}_{5}$ has been associated with a greater tendency towards alteration in glass (Silvestri et al. 2005) and this is borne out by the current study, where P-rich precipitates tend to be associated with glasses that show thicker corrosion patinas (Fig. 6 (b)). 

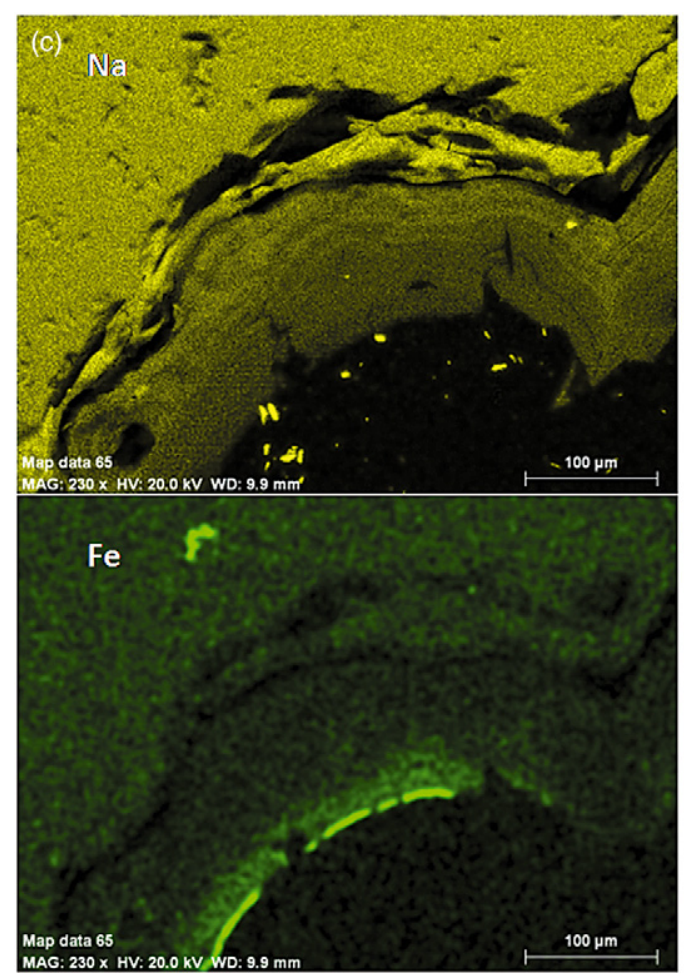

Figure 6 Continued.
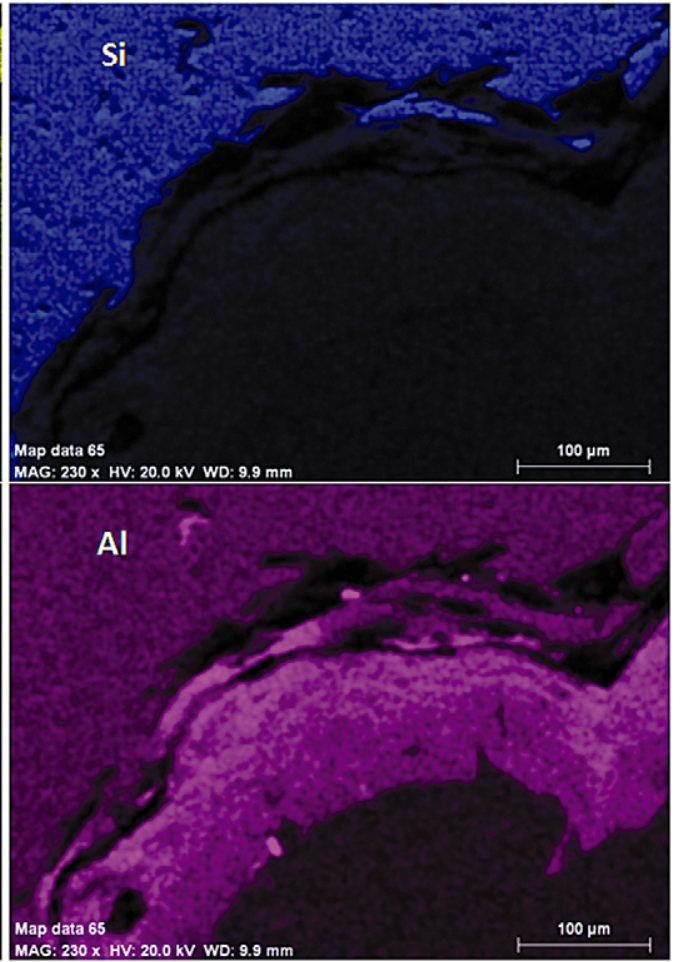

\section{-}

The results of the linescan profiles are confirmed by EDS elemental maps, which clearly show the depletion in $\mathrm{Si}$ and $\mathrm{Na}$ and the $\mathrm{Al}$ enrichment in the corrosion layers, as well as the precipitation of Fe compounds at the outer edge of the corrosion region (Fig. 6 (c)). From these maps, it is also possible to note the absence, at the pristine glass/corrosion interface, of a silica-rich barrier-which is typically present in potash-rich medieval glasses where plant ashes were used as flux (Cox and Ford 1993).

\section{CONCLUSIONS}

While PIXE/PIGE analyses under a helium flux were particularly useful in determining major and minor elemental compositions (including those of light elements such as $\mathrm{Na}$ ) in the pristine glass, BSEM + EDS investigation was essential in examining the nature and microtexture of the corrosion layers and determining compositional trends from pristine to corroded surface regions; whereas SR- $\mu$ XRF proved important to complement the PIXE data through the detection of trace-element distribution patterns in the bulk glass.

The glass samples from the investigated Portuguese sites show a bulk composition typical of Roman glasses; that is, low-Mg, low-K silica-soda-lime glass. The glass colouring agents $(\mathrm{Cu}$, $\mathrm{Fe}$ ) were identified, as well as the decolouring agents $(\mathrm{Mn})$ and opacifiers $(\mathrm{Sb})$ that were probably used to temper the natural green colouring effect of bivalent Fe. The important new findings of the present study are as follows: 
- Na leaching appears to have occurred at a distance of several millimetres from the outer corroded surface in areas which, macroscopically, do not show any sign of corrosion. This also has an important bearing on the choice of the conservation procedure to be applied to glass objects stored in the museum environment, where 'pristine' glass compositional databases need to be compiled for comparative studies.

- Linescan elemental profiles and compositional mapping across the pristine/weathered area interface reveal a general weathering pattern that shows depletion of $\mathrm{Na}, \mathrm{Si}$ and $\mathrm{Ca}$, but $\mathrm{Al}$ and $\mathrm{K}$ enrichment, in the corrosion layers. An external soil source is the most likely explanation for these patterns, with absorption/release reactions involving $\mathrm{K}$ (and $\mathrm{Al}$ ) ions within 2:1 clay minerals being common in soil environments. Such reactions are particularly common in weathering sequences affecting natural glassy volcanic rock sequences, leading to the development of volcanic ash soils.

- The proton microprobe and the synchrotron XRF spectra revealed geochemical association of elements that suggest that the sands used for the glass former contained mineral impurities such as clays, ilmenite, Ti-rich Fe oxides, zircon and columbite. Although not conclusive, this evidence is not incompatible with a possible local provenance of the sand used as the raw material, as columbite-bearing granitic and pegmatitic rocks, as well as rocks bearing Ti-Fe oxides, are present in Portugal.

- The correlation of $\mathrm{Br}$ with $\mathrm{Ca}$ suggests that the geological source for the glass lime stabilizer was marine shells, as opposed to continental limestones.

- The synchrotron XRF maps indicate that the glasses are not homogeneous in composition and that high-temperature stable phases created localized compositional domains.

It is intended to expand the data set by including additional sites in the Portuguese section of the Iberian Peninsula, and to expand the range of analyses to include $\mathrm{O}, \mathrm{Pb}, \mathrm{Sr}$ and $\mathrm{Nd}$ isotopes (Degryse and Schneider 2008), in order to assess whether local glass production centres could be unequivocally identified in the archaeologically important region of southern Iberia.

\section{ACKNOWLEDGEMENTS}

The SR- $\mu$ XRF analyses were financially supported by the EU, under the FP6 Research Infrastructure Action 'Structuring the European Research Area': the assistance of Dr Rolf Simon at the ANKA facility is gratefully acknowledged. The PIXE/PIGE analyses were financially supported by the CHARISMA Project, co-funded by the European Commission within the action 'Research Infrastructures' of the 'Capacities' Programme GA No. FP7-228330. The HERCULES Laboratory infrastructure where the BSEM + EDS analyses were performed gratefully acknowledges financial support from the EEA GRANTS (Iceland-Liechtenstein-Norway). The authors are grateful to the Editor and two anonymous referees, whose suggestions and comments improved the original manuscript. This study was partially funded by the Portuguese 'Fundação para a Ciência e Tecnologia’ (FCT), under the project PTDC/HIS-ARQ/108758/2008.

\section{REFERENCES}

Aerts, A., Janssens, K., and Adams, F., 1999, Trace-level microanalysis of Roman glass from Khirbet Qumran, Israel, Journal of Archaeological Science, 26, 883-91.

Aerts, A., Velde, B., Janssens, K., and Dijkman, W., 2003, Change in silica source in Roman and post-Roman glass, Spectrochimica Acta, B58, 659-67.

Arletti, R., Dalconi, M. C., Quartieri, S., Triscari, M., and Vezzalini, G., 2006, Roman coloured and opaque glass: a chemical and spectroscopic study, Applied Physics, A83, 239-45. 
Barré, P., Velde, B., Fontaine, C., Catel, N., and Abbadie, L., 2008, Which $2: 1$ clay minerals are involved in the soil potassium reservoir? Insights from potassium addition or removal experiments on three temperate grassland soil clay assemblages, Geoderma, 146, 216-23.

Barriga, F. J. A. S., and Fyfe, W. S., 1998, Multi-phase water-rhyolite interaction and ore fluid generation at Aljustrel, Portugal, Mineralium Deposita, 33, 188-207.

Baxter, M. J., Cool, H. E. M., and Jackson, C. M., 2005, Further studies in the compositional variability of colourless Romano-British vessel glass, Archaeometry, 47, 45-68.

Borbély-Kiss, I., Fulop, Z., Gesztely, T., Kiss, A. Z., Koltay, E., and Szabo, G., 1994, The PIXE-PIGE method for the classification of late Roman glass sealings, Nuclear Instruments and Methods in Physics Research, B85, 836-9.

Boschetti, C., Leonelli, C., Corradi, A., Iacumin, P., Martini, M., Sibilia, E., Santoro, S., and Sassi, B., 2008, Glassworking evidences at Durres, Albania: an archaeological and archaeometric study, Journal of Cultural Heritage, 9 , e33-6.

Calligaro, T., 2008, PIXE in the study of archaeological and historical glass, X-Ray Spectrometry, 37, 169-77.

Carmona, N., Ortega-Feliu, I., Gomez-Tubio, B., and Villegas, M. A., 2010, Advantages and disadvantages of PIXE/ PIGE, XRF and EDX spectrometries applied to archaeometric characterization of glasses, Materials Characterization, 61, 257-67.

Climent-Font, A., Munoz-Martin, A., Ynsa, M. D., and Zucchiatti, A., 2008, Quantification of sodium in ancient Roman glasses with ion beam analysis, Nuclear Instruments and Methods in Physics Research, B266, 640-8.

Cox, G. A., and Ford, B. A., 1993, The long-term corrosion of glass, Journal of Materials Science, 28, $5637-47$.

Dal Bianco, B., Bertoncello, R., Milanese, L., and Barison, S., 2004, Glasses on the seabed: surface study of chemical corrosion in sunken Roman glasses, Journal of Non-Crystalline Solids, 343, 91-100.

Degryse, P., and Schneider, J., 2008, Pliny the Elder and Sr-Nd isotopes: tracing the provenance of raw materials for Roman glass production, Journal of Archaeological Science, 35, 1993-2000.

Degryse, P., Schneider, J., Poblome, J., Waelkens, M., Haack, U., and Muchez, P., 2005, A geochemical study of Roman to early Byzantine glass from Sagalassos, SW Turkey, Journal of Archaeological Science, 32, 287-99.

Dias da Cruz, M., 2009, Roman glass from the Iberian Peninsula's northwest: an approach from Bracara Augusta, PhD dissertation, Universidade do Minho, Braga, Portugal.

Folk, R. L., 1980, The petrology of sedimentary rocks, Hemphill, Austin, TX.

Foster, H. E., and Jackson, C. M., 2009, The composition of 'naturally coloured' late Roman vessel glass from Britain and the implications for models of glass production and supply, Journal of Archaeological Science, 36, 189-204.

Fredrickx, P., De Ryck, I., Janssens, K., Schryvers, D., Petit, J. P., and Döcking, H., 2004, EPMA and $\mu$-SXRF analysis and TEM-based microstructure characterization of a set of Roman glass fragments, X-Ray Spectrometry, 33, 32633.

Freestone, I. C., 2005, The provenance of ancient glass through compositional analysis, Materials Research Society Symposium Proceedings, 852, OO8.1.1-13.

Freestone, I. C., 2006, Glass production in Late Antiquity and the Early Islamic period: a geochemical perspective, Geological Society London Special Publications, 257, 201-16.

Freestone, I. C., Leslie, K. A., Thirlwall, M., and Gorin-Rosen, Y., 2003, Strontium isotopes in the investigation of early glass production: Byzantine and Islamic glass from the Near East, Archaeometry, 45, 19-32.

García-Heras, M., Rincón, J. M., Jimeno, A., and Villegas, M. A., 2005, Pre-Roman coloured glass beads from the Iberian Peninsula: a chemico-physical characterization study, Journal of Archaeological Science, 32, 727-38.

Genga, A., Siciliano, M., Famà, L., Filippo, E., Siciliano, T., Mangone, A., Traini, A., and Laganara, C., 2008, Characterization of surface layers formed under natural environmental conditions on medieval glass from Siponto (southern Italy), Materials Chemistry and Physics, 111, 480-5.

Gomez-Tubio, B., Ontalba-Salamanca, M. A., Ortega-Feliu, I, Respaldiza, M. A., Amores-Carredano, F. A., and Gonzalez-Acuña, D., 2006, PIXE-PIGE analysis of late Roman glass fragments, Nuclear Instruments and Methods in Physics Research, B249, 616-21.

Grassi, N., Giuntini, L., Mandò, P. A., and Massi, M., 2007, Advantages of scanning-mode ion beam analysis for the study of cultural heritage, Nuclear Instruments and Methods in Physics Research, B256, 712-18.

Henderson, J., Evans, J. A., Sloane, H. J., Leng, M. J., and Doherty, C., 2005, The use of oxygen, strontium and lead isotopes to provenance ancient glasses in the Middle East, Journal of Archaeological Science, 32(5), 665-73.

Huisman, D. J., Pols, S., Joosten, I., van Os, B. J. H., and Smit, A., 2008, Degradation processes in colourless Roman glass: cases from the Bocholtz burial, Journal of Archaeological Science, 35, 398-411.

Lahil, S., Biron, I., Cotte, M., and Susini, J., 2010, New insight on the in situ crystallization of calcium antimonite opacified glass during the Roman period, Applied Physics, 100, 683-92. 
Lahil, S., Biron, I., Galoisy, L., and Morin, G., 2008, Rediscovering ancient glass technologies through the examination of opacifier crystals, Applied Physics, A92, 109-16.

Leistel, J. M., Marcoux, E., Thieblemont, D., Quesada, C., Sánche, A., Almodovar, G. R., Pascual, E., and Sáez, R., 1998, The volcanic-hosted massive sulphide deposits of the Iberian Pyrite Belt, Mineralium Deposita, 33, 2-30.

Janssens, K., Aerts, A., Vincze, L., Adams, F., Yang, C., Utui, R., Malmqvist, K., Jones, K. W., Radtke, M., Garbe, S., Lechtenberg, F., Knöchel, A., and Wouters, H., 1996, Corrosion phenomena in electron, proton and synchrotron X-ray microprobe analysis of Roman glass from Qumran, Jordan, Nuclear Instruments and Methods in Physics Research, B109/110, 690-5.

Jimenez, J. L., Riuz, E., and Burriel, J. M., 2008, A late Roman industrial complex with glass furnaces in the northern area of Valencia, Journal of Cultural Heritage, 9, 97-100.

Kuisma-Kursula, P., 2000. Accuracy, precision and detection limits of SEM-WDS, SEM-EDS and PIXE in the multielemental analysis of medieval glass, X-Ray Spectrometry, 29, 111-18.

Mäder, M., and Neelmeijer, C., 2004, Proton beam examination of glass - an analytical contribution for preventive conservation, Instruments and Methods in Physics Research, B226, 110-18.

Maxwell, J. A., Teesdale, W. J., and Campbell, J. L., 1995, The Guelph PIXE software package II, Nuclear Instruments and Methods in Physics Research, B95, 407-21.

Messiga, B., and Riccardi, M. P., 2006, Alteration behaviour of glass panes from the medieval Pavia Charterhouse (Italy), Journal of Cultural Heritage, 7, 334-8.

Mirti, P., Casoli, A., and Appolonia, P., 1993, Scientific analysis of Roman glass from Augusta Praetoria, Archaeometry, 35, 225-40.

Ndayiragije, S., and Delvaux, B., 2004, Selective sorption of potassium in a weathering sequence of volcanic ash soils from Guadeloupe, French West Indies, Catena, 56, 185-98.

Patyk-Kara, N. G., Gorelikova, N. V., Bardeeva, E. G., and Shevelev, A. G., 2001, Mineralogy of placers: modern approaches and solutions, Lithology and Mineral Resources, 36(5), 393-405.

Paynter, S., 2006, Analysis of colourless Roman glass from Binchester, County Durham, Journal of Archaeological Science, 33, 1037-57.

Petit, J. C., Della Mea, G., Dran, J. C., Magonthier, M. C., Mando, P. A., and Paccagnella, A., 1990, Hydrated-layer formation during dissolution of complex silicate glasses and minerals, Geochimica et Cosmochimica Acta, 54, 1941-55.

Raw, F., 1955, The long-continued action of water on window glass: weathering of the medieval glass of Weoley Castle, Birmingham, England, Journal of the Society of Glass Technology, 39, 128-33.

Rincón, J. M., 1993, Microstructure and microanalysis (SEM + EDX) determination of glasses from Mallorca and Menorca caves, Trabajos de Prehistoria, 50, 263-6.

Rius, F. X., Larrechi, M. S., Benet, C., Subias, E, Massart, D. L., and Thielemans, A., 1989, The application of multivariate techniques to data from Spanish glass-making objects from the Roman era, Analytica Chimica Acta, 225, 69-81.

Salviulo, G., Silvestri, A., Molin, G., and Bertoncello, R., 2004, An archaeometric study of the bulk and surface weathering characteristics of Early Medieval (5th-7th century) glass from the Po valley, northern Italy, Journal of Archaeological Science, 31, 295-306.

Sayre, E. V., and Smith, R. W., 1961, Compositional categories of ancient glass, Science, 133, 1824-6.

Schreiner, M., Melcher, M., and Uhlir, K., 2007, Scanning electron microscopy and energy dispersive analysis: applications in the field of cultural heritage, Journal of Analytical and Bioanalytical Chemistry, 387, 737-47.

Shortland, A., Schachner, L., Freestone, I. C., and Tite, M., 2006, Natron as a flux in the early vitreous materials industry: sources, beginnings and reasons for decline, Journal of Archaeological Science, 33, 521-30.

Silvestri, A., Molin, G., and Salviulo, G., 2005, Archaeological glass alteration products in marine and land-based environments: morphological, chemical and microtextural characterization, Journal of Non-Crystalline Solids, 351, $1338-49$.

Silvestri, A., Molin, G., and Salviulo, G., 2008, The colourless glass of Iulia Felix, Journal of Archaeological Science, 35, 331-41.

Silvestri, A., Molin, G., Salviulo, G., and Schievenin, R., 2006, Sand for Roman glass production: an experimental and philological study on source of supply, Archaeometry, 48, 415-29.

Smit, Z., Janssens, K., Bulska, E., Wagner, B, Kos, M., and Lazar, I., 2005, Trace element fingerprinting of façon-deVenise glass, Nuclear Instruments and Methods in Physics Research, B239, 94-9.

Solé, V. A., Papillon, E., Cotte, M., Walter, Ph., and Susini, J., 2007, A multiplatform code for the analysis of energy-dispersive X-ray fluorescence spectra, Spectrochimica Acta, B62, 63-8.

Sterpenich, J., and Libourel, G., 2001, Using stained glass windows to understand the durability of toxic waste matrices, Chemical Geology, 174, 181-93. 
Veiga, J. P., and Figuereido, M. O., 2006, Copper blue in an ancient glass bead: a XANES study, Applied Physics, A83, 547-50.

Verità, M., Arena, M. S., Carruba, A. M., and Santopadre, P., 2008, Roman glass: art and technology in a 4th century A.D. opus sectile in Ostia (Rome), Journal of Cultural Heritage, 9, 16-20.

Wagner, B., Novak, A., Bulska, E., Kunicki-Goldfinger, J., Schalm, O., and Janssens, K., 2008, Complementary analysis of historical glass by scanning electron microscopy with energy dispersive X-ray spectroscopy and laser ablation inductively coupled plasma mass spectrometry, Microchimica Acta, 162, 415-24.

Weber, G., Strivay, D., Martinot, L., and Garnir, H. P., 2002, Use of PIXE-PIGE under variable incident angle for ancient glass corrosion measurements, Instruments and Methods in Physics Research, B189, 350-7.

Wickert, C. L., Vieira, A. E., Dehne, J. A., Wang, X., Wilder, D. M., and Barkatt, A., 1999, Effects of salts on silicate glass dissolution in water: kinetics and mechanisms of dissolution and surface cracking, Physics and Chemistry of Glasses, 40(3), 157-70. 